\title{
2018 Genel Seçimlerinde Siyasi Partilerin Ormancılığa Yaklaşımları Üzerine Analizler
}

\author{
Erdoğan ATMİ̧̧ ${ }^{1,2}$, Hikmet Batuhan GÜNŞEN ${ }^{1 *}$ \\ ${ }^{1}$ Bartın Üniversitesi, Bartın Orman Fakültesi, Orman Mühendisliği Bölümü,74100, Bartın \\ ${ }^{2}$ Institute for Environmental Studies (IVM) at Vrije Universiteit Amsterdam, Amsterdam, the Netherlands.
}

\section{Öz}

Siyasi partilerin ormancılığın da içinde olduğu birçok konudaki görüşlerini, özellikle genel seçimler öncesinde hazırlanan bildirgelerde görmek mümkündür. Bu çalışmanın amacı; 24 Haziran 2018 Genel Seçimine katılan siyasi partilerin seçim bildirgelerindeki çevre, ormancılık ve doğa koruma politikalarını ortak bir zeminde analiz etmektir. Seçime katılan partilerin araştırma konusuyla ilgili derine inmeyen politika beyanlarında bulundukları görülmektedir. Vaatleri çoğunlukla slogan düzeyinde kalmakta ve onları gerçekleştirmek için gerçekçi yaklaşımlarda bulunmamaktadırlar. Diğer taraftan siyasi partiler ormanları halen sadece kırsal kesimle ilgili bir varlık olarak görmekte, ormanların uluslararası önemini ve özellikle kentlerde yaşayanlar için değerini kavrayamamaktadır. Ormanların küresel ölçekte değişen rolü ile kentlilere sunduğu hizmetlerin de siyasi partiler tarafından politika oluşturmada dikkate alınması gerekmektedir.

Anahtar Kelimeler: Çevre, korunan alan, orman, politika, yönetim.

\section{Analysis of Political Parties' Approach to Forestry in 2018 General Elections}

\begin{abstract}
It is possible to see the opinions of political parties on many issues, including forestry, especially in the manifestos prepared before the general elections. The aim of this study is to analyse the environmental, forestry and nature conservation policies in manifestos of the political parties participating in the general elections of June 24,2018 . It is seen that the political parties that participated in the general elections have made inadequate policy statements on the subject of this study. Their promises mostly remain at the slogan level and do not make realistic approaches to accomplish them. On the other hand, political parties still regard forests as a rural asset, and they cannot comprehend the international importance and value for the urban residents. The changing role of forests on the global scale and the services provided to the urban residents should be taken into consideration in policy making by the political parties.
\end{abstract}

Keywords: Environment, forest, policy, protected area, administration. 


\section{Giriş}

Toplumsal yapının değişmesine neden olan modernleşme ile savaş, devrim, ekonomik bunalım gibi toplumu sarsan büyük krizler siyasi partilerin kurulmasında önemli rol oynamaktadır. Modernleşme siyasal katılmayı siyasal katılma da siyasal örgütlenmeyi geliştirmektedir. Günümüzdeki anlamıyla 19. yüzyılın ortalarında doğan siyasi partiler, bir program etrafında toplanmış, siyasal iktidarı elde etmek ya da paylaşmak amacını güden, sürekli bir örgüte sahip kuruluşlar olarak tanımlanmaktadır. Siyasi partiler siyasal sistemin niteliği ve karakteri ne olursa olsun çağdaş toplumların hepsinde birinci derecede önemli bir konumdadırlar (Kapani, 2016).

Su ve ormanlar gibi doğal varlıklar ile iktidar arasındaki ilişkinin çok eski zamanlara kadar dayandığı, hatta ormanların yönetilmesinin Orta ve Batı Avrupa'da devlet oluşumunun temel taşını oluşturduğu ifade edilmektedir (Radkau, 2017: 145). Günümüzde de siyasal ve toplumsal alanda, ormanların da önemli bir kısmını oluşturduğu ekolojik düşüncenin önemi her geçen gün daha iyi anlaşılmaktadır (Mutlu, 2008: 120). Ormanlardan sağlanan farklı ürün ve hizmetler toplumun tamamını ilgilendirmekte ve bu durum ormancılığın ekolojik, teknik, teknolojik, ekonomik, politik, toplumsal ve kültürel boyutları olan çok geniş kapsamlı bir etkinlik olduğunu göstermektedir. Bu nedenle dünyanın hangi ülkesinde olursa olsun siyasi partiler de ormanlara ve ormancilığa ilgi göstermektedir. Örneğin, Amerika Birleşik Devletleri’nde (ABD) 1901-1909 yılları arasında iktidarda olan Cumhuriyetçi Parti, yönetiminin merkezine ormancılı̆̆ı ve doğa korumayı yerleştirerek ABD’nin doğal kaynaklar politikasının gidişatını kökten değiş̧irmiştir. Yine ABD'de 1933-1945 döneminde iktidarda olan Demokrat Parti, Büyük Buhran sırasında işsizleri ulusal ormanlarda ve parklarda çalışırımıştır (Cubbage vd., 1993). Bu çerçevede, siyasi partiler ormancılık politikalarının oluşturulmasında ve uygulanmasında önemli ilgi gruplarından birisi olarak görülmektedir (Erdönmez vd., 2010). Benzer şekilde Krott (2005) da ormancillk politikasıyla ilgili alınacak kararlarda üst düzey yönetim, parlamento ve siyasal partilerin katılımının çok önemli olduğunu ifade etmektedir.

Ormancılık politikalarının belirlenmesinde siyasi partilerin özellikle de iktidar partisinin büyük bir paya sahip olması Türkiye'de ormanların ve ormancıllğın siyasal kararlardan dönem dönem olumsuz şekilde etkilenmesine zemin hazırlamıştır (Çağlar, 1979; 2015). Özellikle 1946 yılında çok partili döneme geçildikten sonra görülen bu olumsuzluklar iki kategoride değerlendirilebilir. İlki, siyasi partilerin seçimlerin hemen öncesinde ormancılıkla ilgili yasal değişikliklere başvurmalarıdır. Buna, 14 Mayıs 1950 Genel Seçiminin hemen öncesinde Cumhuriyet Halk Partisi (CHP) iktidarında 31 Mart 1950 tarihinde yayımlanan 5658 sayılı kanunla 1945 yılındaki 4785 sayılı kanunla devletleştirilen bazı orman alanlarından bir kısmının sahiplerine geri verilmesi ile 03 Nisan 1950 tarihinde yayımlanan 5653 sayılı kanunla maki cinsinden her türlü ağaçlıklarla örtülü yerlerin orman sınırı dışına çıkarılmasının kabulü örnek gösterilebilir (REGA, 1950a; 1950b). Bir diğer örnek ise, 29 Kasım 1987 Genel Seçimleri öncesinde Anavatan Partisi'nin iktidarında 28 Mayıs 1987 tarihinde yayımlanan 3373 sayılı kanunla 6831 sayılı Orman Kanununda yapılan değişiklikler ile devlet ormanlarında Orman Genel Müdürlüğü'nce yapılan işlerin bir kısmının başkalarına yaptırılmasının önünün açılmasıdır (REGA, 1987).

Olumsuzluklarla ilgili ikinci kategori siyasi partilerin genel seçimleri kazandıktan sonra seçim bildirgelerinde verdikleri sözleri gerçekleştirmesiyle ilgilidir. Bu konuda örnek olarak; 14 Mayıs 1950 genel seçimlerini kazanarak iktidara gelen Demokrat Parti'nin seçim propagandaları sırasında halka verdiği bazı sözleri gerçekleştirmek için 15 Temmuz 1950 tarihinde yayımlanan 5677 sayılı yasayı çıkarması verilebilir. Bu yasayla genel af çıarılmış ve bununla birlikte orman suçları da affedilmiştir (Günay, 2003). Diğer taraftan, 6831 sayılı Orman Kanunu'nun 2/B maddesine göre orman sınırı dışına çıkartılan alanları ilk iktidara geldiği yıldan beri değerlendirmeyi düşünen Adalet ve Kalkınma Partisi (AK Parti), 2011 genel seçimlerinde "2/B olarak adlandırılan bu arazileri kullanan vatandaşların sorunlarını kökünden çözmek amacıyla, gerekli yasal düzenlemeler tamamlanma aşamasına gelmiş olup, yeni dönemde yasalaşacak ve uygulama başlayacaktır. Böylece vatandaşlarımızı yıllardan beri meşgul eden, kullandıkları, oturdukları bu mekânların gerçek sahibi olmaları önündeki tüm engeller tamamen kalkmış olacaktır” beyanında bulunmuştur (Atmiş ve Günșen, 2011). Nitekim 12 Haziran 2011 Genel Seçimlerini kazanıp iktidarını sürdüren AK Parti 19 Nisan 2012 tarihinde çıkardığı 6292 sayılı yasayla 2/B ile ilgili vatandaşa verdiği beyanını gerçekleştirmiştir.

Şüphesiz ki bu iki kategori de; siyasi partilerin sırf halkın oyunu alıp iktidarlarını sürdürebilmek için ormanlara zarar verebilecek politikalar ortaya koyduklarını açıkça göstermektedir. Oysa ormancılık politikasının partiler üstü bir niteliğe sahip olması, iç politika aracı yapılmaması ve iktidar değişikliklerinden etkilenmemesinin ülke ormancılığının başarılı olmasını sağlayacak önemli unsurlar olduğu unutulmamalıdır (Eryılmaz, 1985). Hedeflenen ulusal ormancılık politikası amaçlarına ulaşılabilmek için öncelikle saptanan amaçların tüm ilgili kişi, grup veya örgütlerce benimsenmiş olmasında yarar bulunmaktadır (Gümüş, 2004). 
Demokrasi ilkesinin temel özelliklerinden biri, özgür ve eşit şartlarda yapılan seçimlerin varlığıdır (Çelik, 2012: 109). Çok partili temsili demokrasilerde yasama işlevini yerine getirecek ve yönetim erkini kullanacaklar bu seçimlerle iş başına gelmektedir (Kiriş ve Gül, 2008: 101). Siyasi partiler genel seçimlerden önce hazırladıkları bildirgelerle eğitim, kalkınma, çevre, ormancılık, ekonomik büyüme, kentleşme, sağlık ve dış ilişkiler gibi konulardaki politika önerilerini topluma sunmaktadır (Atmiş ve Günşen, 2011, 2016; Quinn, 2010). Seçim bildirgeleri siyasi partilerin resmi politika beyanları olduğundan, partilerin politika öncelikleri ve tercihlerini incelemeye yarayan değerli kaynaklardır (Aytaç, 2017).

Türkiye'de farklı disiplinler siyasi partilerin politikalarını değerlendirebilmek için seçim bildirgelerini incelemektedir. Aytaç (2017) siyasi partilerin öncelikli politika alanlarını belirleyebilmek için 2002-2015 döneminde AK Parti, CHP, MHP ve HDP'nin beyannamelerini/bildirgelerini internette bulunan bir veri tabanı üzerinden değerlendirmiş ve partilerin en sık ekonomi ile refah ve yaşam kalitesi alanlarına ilişkin politika önerilerinin bulunduğunu tespit etmiştir. Araştırmadaki dikkat çeken bir diğer önemli sonuç ise AK Parti'nin ekonomi ile refah ve yaşam kalitesi alanları arasında ekonomiye sürekli olarak daha fazla öncelik vermiş olmasıdır. $\mathrm{Bu}$ araştırmanın dışında sadece belli bir alandaki politikaların seçim bildirgeleri aracılığıyla değerlendirildiği araştırmalar da bulunmaktadır. Örneğin, Çarkoğlu (1998) partilerin ideolojilerindeki değişimleri, Tok (2012) eğitim politikalarını, Tiyek (2015) sosyal politikalarını, Aymankuy vd. (2016) turizm politikalarını, Şeşen ve Ertürk (2017) çevre politikalarını ve Akçay (2018) da Avrupa Birliği ilişkileriyle ilgili politikalarını seçim bildirgelerinden yararlanarak incelemiştir.

Çağlar (2007) farklı disiplinlerin araştırmalarında materyal olarak kullanılabilen seçim bildirgelerini; "ormanlarımızın içinde bulunduğu koşullara, giderek artan önemlerine, kamuoyunun çeşitlenerek artan ormancılık hizmeti beklentilerine, olası iklim değişikliklerinin gündeme getirebileceği ekolojik yıkımlara karşın siyasal partilerin ormanlarımıza ve ormancılığımıza yaklaşımlarını sergileyen önemli belgeler" olarak görmektedir. Siyasi partilerin ormancılık politikalarının değerlendirmesinde Coşkun vd. (2015) tek başına iktidar olan partilerin seçim bildirgelerini ve programlarını incelemişlerdir. Atmiş $(2003 ; 2008)$ ile Atmiş ve Günşen $(2011$; 2016) ise 2003-2015 yılları arasındaki genel seçimlere giren tüm siyasi partilerin seçim bildirgelerini inceleyerek partilerin çevre, ormancılık ve doğa koruma politikalarının karşılaştırmalı analizini yapmıştır. Tabii ki siyasi partilerin orman ve ormancılıkla ilgili görüşlerinin tamamını seçim bildirgelerinde bulmak mümkün değildir. Fakat metin içindeki ormanlar ve ormancılıkla ilgili sarf edilen ifadeleri analiz etmek mümkündür. Atmiş $(2003 ; 2008)$ ile Atmiş ve Günşen $(2011 ; 2016)$ tarafından yapılan çalışmaların devamı niteliğinde olan bu çalışma; 24 Haziran 2018 Genel Seçimleri için siyasi partilerin hazırladıkları seçim bildirgelerinde yer alan çevre, orman ve doğa koruma politikalarını ortak bir zeminde analiz etmek amacıyla yapılmıştır.

\section{Materyal ve Metot}

Türkiye'de Cumhuriyet Halk Partisi’nin (CHP) iktidarda olduğu 1923-1946 yılları arasındaki tek partili dönem 7 Ocak 1946'da CHP'den ayrılanların Demokrat Parti'yi kurmasıyla birlikte sona ermiş ve Türkiye'de çok partili demokratik bir siyasi yaşama fiilen geçilmiştir (Günay, 2003). Çok partili dönemden itibaren Türkiye'nin siyasal hayatında yer alan partilerin önemli bir bölümünün mevcut partilerin fikir ayrılıklarıyla bölünmeleri veya birleşmeleri sonucunda ortaya çıktığı görülmektedir (Karpat, 2013). Türkiye Cumhuriyeti Yargıtay Başkanlığı'nın 2018 yılı resmi kayıtlarına göre; Türkiye'de faaliyette olan 84 siyasi parti bulunmaktadır (Yargitay, 2018). Türkiye Büyük Millet Meclisi'nde (TBMM) 20 Nisan 2018 tarihinde alınan erken seçim kararıyla 24 Haziran 2018 tarihinde genel seçim yapılmasına karar verilmiştir. Seçimlere sekiz siyasi parti girmiştir. Seçim sonucunda geçerli oyların \%42,56'sını AK Parti, \%22,65'ini CHP, \%11,7'sini HDP, \%11,1'ini MHP ve \%9,96'sını İP almıştır (Tablo 1).

Tablo 1. Siyasal partilerin 24 haziran 2018 genel seçimindeki yurt içi, yurt dışı ve gümrük sandıkları dâhil oy sayısı ve oranları (YSK, 2018).

\begin{tabular}{llrr}
\hline \multicolumn{1}{c}{ Parti Adı* } & Kısaltma** $^{*}$ & Seçmen sayısı & Oy Oranı (\%) \\
\hline Adalet ve Kalkınma Partisi & AK Parti & 21.338 .693 & 42,56 \\
Cumhuriyet Halk Partisi & CHP & 11.354 .190 & 22,65 \\
Halkların Demokratik Partisi & HDP & 5.867 .302 & 11,70 \\
Milliyetçi Hareket Partisi & MHP & 5.565 .331 & 11,10 \\
İyi Parti & IPP & 4.993 .479 & 9,96 \\
Saadet Partisi & SP & 672.139 & 1,34 \\
Hür Dava Partisi & & 155.539 & 0,31 \\
Vatan Partisi & VP & 114.872 & 0,23 \\
Bağımsızlar & & 75.630 & 0,15 \\
\hline Toplam & & 50.137 .175 & $\mathbf{1 0 0}$ \\
\hline
\end{tabular}


*Italik olarak yazılan Hur Dava Partisi’nin seçim bildirgesine ulaşılamamıştır. **Makalenin geri kalan kısmında partiler için bu kısaltmalar kullanılacaktır.

Çalışmada 24 Haziran 2018 genel seçimine katılan sekiz siyasi partiden yedisinin seçim bildirgeleri (beyannameleri) incelenerek ormancılıkla ilgili yaklaşımları/tutumları ortaya konmaya çalışılmıştır. Bunun için belgesel tarama yöntemi ile partilerin seçim bildirgelerine resmi internet sayfaları üzerinden ulaşılmıştır. Hür Dava Partisinin seçim bildirgesine hiçbir şekilde ulaşılamadığı için bu parti değerlendirme dışı bırakılmıştır. Nitel veri toplama yöntemlerinden biri olan, var olan kayıt ve belgeleri inceleyerek veri toplamaya belgesel tarama denilmektedir. Belgesel tarama, belli bir amaca dönük olarak, kaynakları bulma, okuma, not alma ve değerlendirme işlemlerini kapsamaktadır (Bowen, 2009).

Elde edilen siyasi parti bildirgeleri çevre, yeşil alanlar, korunan alanlar, doğa koruma, orman ve ormancilık gibi konuları göz önünde bulundurularak tek tek incelenmiştir. Daha önce Atmiş $(2003 ; 2008)$ ile Atmiş ve Günşen (2011, 2016) tarafından yapılan çalışmalar da kullanılan sözcükler dikkate alınarak 46 sözcük belirlenmiştir (Tablo 2). Etkinlik alanları birbirine yakın olan sözcükler Çevre, Doğa Koruma ve Ormancılık olmak üzere üç temel başlık altında sınıflandırılmıştır. "Doğa" ve "Tabiat" ya da "Küresel Isınma" ve "İklim Değişikliğii" gibi anlam olarak aynı fakat yazılışı farklı olan sözcükler de göz önünde bulundurulmuş ve tek bir sözcük olarak sayılmışlardır. Bu sözcüklerin siyasi partilerin seçim bildirgelerinde ne kadar sıklıkla kullanıldığı içerik analizi ile belirlenmiş ve bildirgeler karşılaştırılmıştır. Bu analiz uzun metinler içinde, araştırma sorusu açısından önem arz eden ortak bilgileri tespit etmede ve değerlendirmede kullanılmaktadır (Neuendorf, 2017). İçerik analizi hem siyasi partiler (Tokgöz, 1994: 26) hem de ormancılık politikalarıyla (Atmiş ve Günşen, 2011: 193; Atmiş ve Günşen, 2016: 590; Günşen ve Atmiş, 2017: 209; Yurdakul Erol ve Yıldırım, 2017: 2) ilgili araştırmalarda kullanılmaktadır.

İçerik analizinden sonra siyasi partilerin ormancılık, çevre ve doğa koruma konularına bakışları yedi başlık altında sorgulanmıştır. Burada özellikle siyasi partilerin seçim bildirgelerindeki ifadeleri karşılaştırılmış ve ilgili konular hakkında yapılan bilimsel çalışmalar dikkate alınarak tartışılmıştır. Her partinin çalışmaya konu olan görüşleri o partinin seçim bildirgesinden alıntılandığından, Bulgular kısmında parti görüşlerini içeren alıntıların metin içi atıfları her parti için bir kere verilmiş, daha sonraki alıntılarda karışıklık olmaması için verilmemiştir.

\section{Bulgular ve Tartışma}

\subsection{Seçim Bildirgelerinde Taranan Sözcüklerle İlgili Genel Değerlendirme}

$\mathrm{Bu}$ bölümde daha önceden belirlenmiş ve parti seçim bildirgelerinde içerik analizi ile taranan sözcüklerin değerlendirmesi yapılmıştır. Belirlenen sözcüklere en çok değinen parti 278 sözcükle $A K$ Parti olmuştur. Bunu sirayla 136 sözcükle $C H P, 67$ sözcükle $I P, 53$ sözcükle $S P, 40$ sözcükle $H D P, 37$ sözcükle $M H P$ ve 25 sözcükle $V P$ takip etmiştir (Tablo 2). Partiler en çok çevre ile ilgili sözcüklere yer vermiş ve bunu sırasıyla ormancılık ve doğa koruma ile ilgili sözcükler takip etmiştir. 2015 yılı genel seçimlerinde de siyasi partiler en çoktan en aza çevre, ormancılık ve doğa koruma konularında sözcükleri kullanmıştır (Atmiş ve Günşen, 2016).

Çevre başlığı altında en çok 'doğa/doğal/tabiat' sözcüğü kullanılmıştır (174). Bu sözcüğü sırasıyla 'havza' ve 'kırsal kalkınma' takip etmektedir. Bu üç sözcüğe siyasi partiler içinde en fazla $A K$ Parti yer vermiştir. Çevre ile ilgili olan 'küresel 1sınma/iklim değişikliği' sözcüğüne en çok $C H P$, 'Ekoloji' sözcügüne ise $I P$ yer vermiştir. Siyasi partilerin seçim bildirgelerinde sayıca fazla kullandıkları sözcükler aynı zamanda onların önemsediği alanları da göstermektedir. Bunlarla ilgili niteliksel değerlendirmeler diğer ilgili başlıklar altında yapılmıştır. 'Habitat' sözcüğüne ise hiçbir siyasi parti seçim bildirgesinde değinmemiştir (Tablo 2).

Ormancılık konusu kapsamında siyasi partiler en çok sırasıyla 'orman', 'mera' ve 'ağaçlandırma' sözcüklerini kullanmışlardır. 'Orman' ve 'ağaçlandırma' sözcüklerine en çok AK Parti seçim beyannamesinde yer verirken, 'mera' sözcüğüne en çok $I P$ değinmiştir. 'Orman köyü/köylüsü' sözcüğünü ise en çok $C H P$ kullanmıştır. 'Orman işçisi’ sözcüğüne sadece $V P$, ‘orman kanunu/mevzuatı' sözcügüne $C H P$, 'orman amenajmanı' sözcügüne $S P$ ve 'sürdürülebilir orman yönetimi' ne $\dot{I P}$ değinmiştir. Ormancıllk örgütü ve yönetimiyle ilgili AK Parti iktidarı tarafından zaman zaman değişiklikler yapılmış ve bu değişikliklerin sakıncaları Gümüş (2014) ile Akay ve Akgün (2014) gibi araştırmacılar tarafından dile getirilmiştir. Ne yazık ki buna rağmen 'Ormancılık örgütü/orman ve su işleri bakanlığı', 'orman suçu' ve 'sürdürülebilir ormancılık' sözcüklerine hiçbir siyasi parti seçim bildirgelerinde yer vermemiştir. $C H P, H D P$ ve $V P$ ’nin kırsal kalkınma sözcüğüne hiç değinmemiş olmaları ilginçtir (Tablo 2). 
Siyasi partiler tarafından doğa korumayla ilgili en çok sırasıyla 'yaban hayatı/hayvanı', 'korunan alan' ve 'biyolojik çeşitlilik' kavramları kullanılmıştır. Bunların üçünü de en çok kullanan siyasi parti AK Parti olmuştur. $H D P$ ve $\dot{I P}$ doğa koruma konusuyla ilgili hiçbir sözcüğe bildirgelerinde yer vermemiştir. 'Muhafaza ormanı' sözcüğüne ise hiçbir parti değinmemiştir (Tablo 2).

Tablo 2. Partilerin seçim bildirgelerinde kullandıkları çevre, doğa koruma ve ormancılıkla ilgili terimler.

\begin{tabular}{|c|c|c|c|c|c|c|c|c|c|}
\hline & & $\begin{array}{c}\text { AK } \\
\text { Parti }\end{array}$ & $\mathrm{CHP}$ & $\begin{array}{c}M H \\
P\end{array}$ & HDP & $S P$ & $V P$ & $\dot{I P}$ & Toplam \\
\hline \multirow{18}{*}{$\overbrace{0}^{0}$} & Doğa/Doğal/Tabiat & 52 & 42 & 13 & 22 & 16 & 6 & 23 & 174 \\
\hline & Doğal Kaynak & 11 & 7 & 3 & 0 & 1 & 1 & 4 & 27 \\
\hline & Ekoloji/Ekolojik & 2 & 3 & 1 & 7 & 1 & 0 & 8 & 22 \\
\hline & Ekosistem & 2 & 2 & 1 & 1 & 1 & 0 & 1 & 8 \\
\hline & Endemik & 0 & 1 & 0 & 0 & 0 & 0 & 0 & 1 \\
\hline & Erozyon & 5 & 2 & 0 & 0 & 1 & 1 & 1 & 10 \\
\hline & Habitat & 0 & 0 & 0 & 0 & 0 & 0 & 0 & 0 \\
\hline & Çevrenin Korunması & 5 & 2 & 2 & 0 & 3 & 0 & 1 & 13 \\
\hline & Küresel Isınma/İklim Değişikliği & 4 & 13 & 1 & 0 & 2 & 0 & 3 & 23 \\
\hline & Sera gazı & 3 & 1 & 0 & 0 & 0 & 1 & 0 & 5 \\
\hline & Sür. Kalkınma & 4 & 1 & 4 & 0 & 1 & 0 & 0 & 9 \\
\hline & Kırsal Kalkınma & 24 & 0 & 3 & 0 & 4 & 0 & 1 & 32 \\
\hline & Ekoturizm/Doğa turizmi & 3 & 0 & 0 & 0 & 0 & 0 & 0 & 3 \\
\hline & HES & 8 & 1 & 0 & 2 & 1 & 0 & 0 & 12 \\
\hline & ÇED & 5 & 5 & 0 & 1 & 3 & 0 & 0 & 15 \\
\hline & Havza & 27 & 2 & 3 & 0 & 2 & 0 & 0 & 34 \\
\hline & Yeşil alan/yeşil kuşak & 11 & 1 & 0 & 0 & 1 & 1 & 1 & 16 \\
\hline & Botanik/Botanik bahçe & 1 & 0 & 0 & 0 & 0 & 0 & 1 & 2 \\
\hline \multirow{9}{*}{ 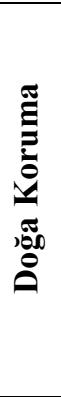 } & Yaban Hayat1/Hayvanı & 11 & 1 & 1 & 0 & 1 & 1 & 0 & 15 \\
\hline & $\begin{array}{l}\text { Biyolojik Çeşitlilik / Biyoçeşitlilik / } \\
\text { Zenginlik }\end{array}$ & 7 & 2 & 1 & 0 & 0 & 1 & 0 & 11 \\
\hline & Doğa koruma & 0 & 0 & 0 & 0 & 0 & 1 & 0 & 0 \\
\hline & Korunan Alan & 12 & 0 & 0 & 0 & 1 & 0 & 0 & 13 \\
\hline & Milli Park & 6 & 0 & 0 & 0 & 1 & 0 & 0 & 7 \\
\hline & Tabiat Park1 & 2 & 0 & 0 & 0 & 1 & 0 & 0 & 3 \\
\hline & Tabiatı Koruma Alanı & 2 & 0 & 0 & 0 & 1 & 0 & 0 & 3 \\
\hline & Tabiat Anitı & 1 & 0 & 0 & 0 & 0 & 0 & 0 & 1 \\
\hline & Muhafaza Ormanı & 0 & 0 & 0 & 0 & 0 & 0 & 0 & 0 \\
\hline \multirow{20}{*}{ 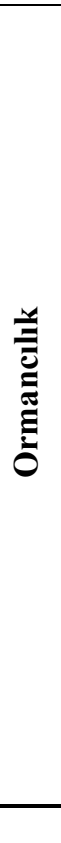 } & Orman & 35 & 25 & 2 & 5 & 6 & 3 & 10 & 85 \\
\hline & Kent (Şehir) Ormanı & 4 & 0 & 0 & 0 & 0 & 0 & 0 & 4 \\
\hline & Orman Köylüsü/Köyü & 5 & 8 & 1 & 0 & 0 & 0 & 0 & 14 \\
\hline & Orman işçisi & 0 & 0 & 0 & 0 & 0 & 1 & 0 & 1 \\
\hline & Orman Yangını & 2 & 0 & 0 & 0 & 0 & 0 & 0 & 2 \\
\hline & Orman Ürünü/Ürünleri & 4 & 2 & 0 & 0 & 0 & 0 & 0 & 6 \\
\hline & $\begin{array}{l}\text { Ormanc1lık Örgütü /Orman } \\
\text { Bakanlığı }\end{array}$ & 0 & 0 & 0 & 0 & 0 & 0 & 0 & 0 \\
\hline & Orman Kanunu /Mevzuatı & 0 & 1 & 0 & 0 & 0 & 0 & 0 & 1 \\
\hline & 2/B & 5 & 1 & 1 & 0 & 0 & 0 & 1 & 9 \\
\hline & Orman Kadastrosu & 1 & 0 & 0 & 0 & 1 & 0 & 0 & 2 \\
\hline & Ormancılık/Tarımsal Kooperatifi & 1 & 3 & 0 & 0 & 0 & 0 & 0 & 2 \\
\hline & Orman Amenajmanı & 0 & 0 & 0 & 0 & 1 & 0 & 0 & 1 \\
\hline & Orman suçu & 0 & 0 & 0 & 0 & 0 & 0 & 0 & 0 \\
\hline & Ormancilik & 2 & 5 & 0 & 0 & 0 & 0 & 0 & 7 \\
\hline & Sür. Ormancılık & 0 & 0 & 0 & 0 & 0 & 0 & 0 & 0 \\
\hline & Sür. Orman Yönetimi & 0 & 0 & 0 & 0 & 0 & 0 & 1 & 1 \\
\hline & Ağaçlandırma & 7 & 1 & 0 & 0 & 0 & 5 & 4 & 17 \\
\hline & Mesire yeri & 2 & 0 & 0 & 0 & 0 & 0 & 0 & 2 \\
\hline & Mera & 2 & 5 & 0 & 2 & 4 & 4 & 6 & 23 \\
\hline & TOPLAM & 278 & 136 & 37 & 40 & 53 & 25 & 67 & 636 \\
\hline
\end{tabular}




\subsection{Orman Mülkiyeti ve İşletmeciliği}

Türkiye'nin uzun süre gündeminde olan 6831 sayılı Orman Kanunu'nun 2/B maddesini uygulama vaadi genel seçimlerde halkın oyunu alabilmek için sıklıkla kullanılmıştır. $A K$ Parti seçim beyannamesinde orman kadastrosu çalışmalarını tamamladıklarını bildirerek "Kamuoyunda 2/B olarak bilinen orman vasfını yitirmiş arazilerin değerlendirilmesi ve satışı konusunda düzenleme" yaptığını ve bu düzenlemeyle "40 yıldır çözülemeyen ve vatandaş ile devleti karşı karşıya getiren meseleyi” çözdüğ̈̈nü iddia etmektedir. AK Parti bu kapsamda, 2/B arazilerindeki toplam 517 bin adet taşınmazın satılıp 724 bin hak sahibine tapularının verildiğini, ayrıca kalan 100 bin adet 2/B taşınmazının 160 bin kullanıcıya satılacağını beyan etmektedir (AK Parti, 2018). Ancak, AK Parti hükümetinin 2/B sorununu kendince çözmek için 26.04.2012 tarihinde çıkardığı 6292 sayılı kanunun Anayasa'ya ve Anayasa Mahkemesi kararlarına aykırı hükümler taşıdığı (Yıldırım ve Ayanoğlu, 2014) ve Türkiye Ulusal Ormancıllk Programının ilke, amaç, politika ve stratejileriyle büyük ölçüde uyumsuz olduğu (Erdönmez, 2013) dile getirilmektedir. Görünen odur ki AK Parti hükümeti orman sınırı dışına çıkarılan alanların sadece satışıyla ilgili düzenleme yapmıştır. Sorunun temelini oluşturan Anayasa'nın 169. Maddesinin 4. paragrafı ve buna bağlı olarak 6831 sayılı Orman Kanunu'nun 2. Maddesinin B bendi kaynaklı sorunu kalıcı olarak çözecek şekilde herhangi bir yasal düzenleme yapılmamıştır.

MHP de seçim beyannamesinde; 1 Kasım 2015 genel seçimlerindeki "2/B sorununun adil ve hakkaniyete uygun şekilde çözüme kavuşturulacak" taahhüdünün, 26. Yasama Döneminde MHP'li milletvekilleri tarafından takip edilerek kısmen ya da tamamen gerçekleştirildiğini ifade etmektedir (MHP, 2018).

CHP ise seçildikleri takdirde imar affı ile "2/B arazisinde binası olan yurttaşlarımızın mağduriyetlerini gidereceğiz" diyerek aslında ormanların aleyhine bir beyanda bulunurken diğer taraftan "Orman alanlarının daraltılmasına ve özelleştirilmesine izin vermeyeceğiz" ifadesini kullanmaktadır (CHP, 2018). Seçime katılan partiler arasında sadece $I P$ ormanların lehinde olacak şekilde "orman vasfını yitirdiği gerekçesiyle orman sınırları dışına çıkarılan sahaları, ekosistemin korunması amacıyla yeniden ağaçlandıracağız. Özel çıkar amacıyla yeni sahaların tahribini engelleyeceğiz ve caydırıcı düzenlemeler yapacağız" beyanında bulunmuştur. Ancak bu düzenlemelerle ilgili ayrıntılı bilgi vermemiştir. Bunun dışında IP Çiftçi Çağrı Merkezi kurarak "2B arazi hukuku" konularında da çiftçilerin sorularına yanıt vereceklerini bildirmektedir. Ancak bu bölümde ormandan hiç bahsedilmemektedir (İP, 2018).

Ormanların işletilmesiyle ilgili olarak CHP seçim bildirgesinde "Devlet ormanlarının devlet tarafindan işletilmesini sağlayacağız." ifadesine yer vermektedir. Ancak Anayasa'nın 169. Maddesine göre zaten devlet ormanları kanuna göre devletçe yönetilmekte ve işletilmektedir. $M H P$ ise "Ormanların korunması ve işletilmesinde çok amaçlı yararlanma, devamlılık, katılımcılık, biyolojik çeşitlilik, uzmanlaşma, su ve yaban hayatının ve ekosistemin etkin korunması hususları dikkate alınmalıdır" vurgusunu yapmaktadır.

Orman Genel Müdürlüğü daha verimli ve rasyonel bir işletmecilik yapacağı iddiasıyla dikili ağaç satışlarına ağırlık vermeye başlamıştır (OGM, 2012). Ancak bu uygulama ormancılık örgütü ile orman köylüsü arasında çatışmaların doğmasına neden olmuştur (Daşdemir, 2011). CHP "Ormancılık işlerinde ve satışlarında, dikili ağaç satışı uygulamasına son vereceğiz." beyanıyla bu sorunu orman köylüsünden yana çözeceğini belirtmektedir.

AK Parti 2002 yılından beri iktidarda olduğu için bu süreç içinde yapılan ormancıllı işletmesiyle ilgili çalışmalara da atıf yaparak beyanda bulunmaktadır. Örneğin, orman ürünleri sanayisini güçlendirerek büyüttüklerini ve 2002 yılında 13,7 milyon $\mathrm{m}^{3}$ olan endüstriyel odun üretimini 2017 y1lında 17,1 milyon $\mathrm{m}^{3}$ e çıkardıklarını ifade etmektedir. Oysa Orman Genel Müdürlüğü'nün resmi rakamlarına göre 2002 yılında 8 milyon $\mathrm{m}^{3} 2017$ yılında ise 15,5 milyon $\mathrm{m}^{3}$ endüstriyel odun üretimi yapılmıştır (OGM, 2018). AK Parti'nin seçim beyannamesinde kullandığı rakamlar ile Orman Genel Müdürlüğ̈̈’nün resmi rakamları uyuşmamaktadır. AK Parti seçim beyannamesinde abartılı rakamlar kullanmıştır. AK Parti orman ürünleri sanayinde büyük bir atılım gerçekleştirerek endüstriyel odun üretimini 2023 yılında 21 milyon $\mathrm{m}^{3}$ 'e ulaştıracağını beyan etmektedir. Endüstriyel odun üretimindeki bu olağan üstü artış $A K$ Parti hükümetinin odun üretimi yapmak için ormanlara aşırı şekilde yüklendiğini göstermektedir (Atmiş ve Günşen, 2018a).

Odun dışı orman ürünlerinin de orman ürünleri sanayinde önemli bir yeri bulunmaktadır. Tıbbi ve aromatik bitkilerin geliştirilmesine destekler verdiğini belirten $A K$ Parti, ormanlardan elde edilen kekik, adaçayı, defne, keçiboynuzu gibi odun dışı orman ürünleri ihracat gelirini 507 milyon dolara çıkardığını ve bu rakamı 2023 yılına kadar 5 milyar dolara ulaştıracağını vaat etmektedir. AK Parti ürünlerin işlenip katma değer yaratılmasından çok sadece niceliksel bir ihracat artışından bahsetmektedir. Bu konuda CHP ise "Doğal orman ürünlerinin hammadde olarak kullanıldığı ilaç ve kozmetik endüstrisine yatırım yaparak, katma değeri yüksek 
ürünler elde edeceğiz.” beyanında bulunmaktadır. Türkiye odun dışı orman ürünleri açısından yüksek bir potansiyele sahiptir. Ancak bu ürünlerin sadece hammadde olarak ihraç edilmesi ülke ormancilığında önemli darboğazlardan biri olarak görülmektedir (Günşen ve Atmiş, 2018; OGM, 2012). Bu bakımdan CHP'nin beyanı, odun dışı orman ürünlerinin değerlendirilmesinde yaşanan darboğazı aşmak için daha uygun bir seçenektir.

AK Parti seçim beyannamesinde meralarla ilgili olarak iktidarda olduğu dönemde "Göçerlere mera kiralaması süresini 1 yıldan 5+5 olmak üzere 10 yıla çıkardık." diyerek kırsal toplulukları ve kırsal kalkınmayı destekleyici bir tavır ortaya koymaktadır. HDP ise iktidarda bulunan $A K$ Parti'nin doğal kaynaklar üstündeki tahrip edici neoliberal ekonomi politikalarını eleştirerek, seçim bildirgesinde "Tarım alanlarının, ormanların ve meraların sermaye projelerinde kullanılmasına izin vermeyeceklerini" ve "Bu projeler için tahrip edilen orman alanlarını yapılaşmaya açmayacaklarını" beyan etmektedir (HDP, 2018). Diğer taraftan "Nükleere ve radyoaktiviteye dayalı üretim ve yeniden dönüşüm yapılanmasına, tarım alanlarının, meraların, ormanların, kıyıların nükleer atık sahası olmasına izin vermeyeceğiz." diyerek HDP aslında ormanların amaç dışı kullanımlara tahsis edilmesine engel olacağını dile getirmektedir. Benzer şekilde $S P$ beyannamesinde "kentleşme, sanayileşme ve yapılaşmada ormanlar, meralar ve tarım alanları kullanılmayacaktır" demekte (SP, 2018), CHP ise "Meraları özel mülkiyet olmaktan çıkaracağız" ve "Mera Yönetim Birlikleri'ni etkinleştirecek, 1slah edeceğimiz meraların amaç dış1 kullanımına izin vermeyeceğiz. Meraların köyün ortak malı olarak kalmasını sağlayacağız.” beyanlarında bulunmaktadır.

IPP meralarla ilgili olarak "Meraları, köy tüzel kişiliğine devredeceğiz, meraların ıslah edilmesini sağlayacağız. Büyükşehir Yasası'nda yapacağımız değişiklik ile mera, yaylak ve kışlakları köy tüzel kişiliğine tekrar devredeceğiz. Hayvancılığı geliştirme ve sürdürme politikamızın temelini oluşturan meraların köy tüzel kişilikleri tarafından kullanım hakkını yok eden yasal düzenlemeleri iptal edeceğiz ve meraların 1slah edilmesini sağlayacağız." beyanında bulunmaktadır. VP terör nedeniyle kullanılamayan mera alanlarını, Doğu ve Güneydoğu illerine huzur getirerek hayvancılığa açacakları ve besicileri destekleyecekleri vaadinde bulunmakta ve “Köy merası, köylünündür. Meralarımızı kurtaracağız.” sloganını kullanmaktadır (VP, 2018).

Orman alanlarıyla ilgili olarak AK Parti Türkiye'nin "Dünyada orman varlığını arttıran nadir ülkelerden birisi" olduğunu ve "2002 yılında 208 milyon dekar olan orman varlığını 223 milyon dekara" çıkardığını bildirmektedir. AK Parti daha yeşil bir Türkiye için hedefini "2023 yılı sonuna kadar orman alanlarını, ülke yüzölçümünün yüzde 30'una denk gelen 233 milyon dekara yükseltmek" olarak belirlemiştir. AK Parti ilk defa iktidara geldiği 2002 yılını temel alarak karşılaştırmalar yapmaktadır. Örneğin beyannamesinde 2002 yılında Türkiye'deki orman varlığının 208 milyon dekar olduğunun bilgisini vermektedir. Oysa 1999 yılında orman alanlarının 208 milyon dekar (tam olarak 20.763.248 ha) olduğu tespit edilmiş, 2002 yılında ise ülke orman alanlarının ölçümüyle ilgili her hangi bir işlem yapılmamıştır (OGM, 2018). Diğer taraftan ülke orman alanlarında geçmişten günümüze bir artış olmuştur. Ancak bu artışın ana nedeni AK Parti'nin iddia ettiği gibi ağaçlandırmalarla sağlanan "başarı" değil, sosyo-ekonomik gelişmelerle beraber ülke nüfusunun ağırlığının kırdan kente doğru kayması ve kırsal alanlarda terkedilen tarım ve mera alanlarının kendiliğinden ormana dönüşüyor olmasıdır (Günşen ve Atmiş, 2019).

\subsection{Orman Toplum İlişkileri}

Beyannamesinde ilk olarak genel seçimden önceki süreçte neler yaptığından bahseden AK Parti "ormancılık faaliyetlerini geliştirmek ve orman köylümüzü desteklemek maksadiyla ceviz, badem, kestane, dut, salep, trüf mantarı, yol kenarı ağaçlandırması gibi 38 farklı alanda Eylem Planları hazırlayarak uygulamaya" koyduğunu bildirmektedir. AK Parti 2015 genel seçimi beyannamesinde ilk defa yer verdiği orman köylüsünü yerinde kalkındırma vaadini yerine getirmek amacıyla "5 Bin Köye, 5 Bin Gelir Getirici Orman” projesini başlattığını ve orman köylüsüne 16 yılda doğrudan destekler ve ormancılık faaliyetlerinden 14,5 milyar TL gelir sağladığını dile getirmektedir. Orman köylüsüne verdiği desteklere devam edeceğini beyan eden AK Parti başlatılan "5 Bin Köye, 5 Bin Gelir Getirici Orman” projesi çerçevesinde meyveli orman ağaçları dikilmesine devam edileceğini ve bal ormanı sayısını 700'e çıkarılacağını bu sayede de orman köylüsüne ilave 8 milyar TL gelir sağlayacağını bildirmektedir.

AK Parti diğer yandan kırsal alandaki kooperatiflere vermiş olduğunu desteği vurgulamak için beyannamesinde “1990-2002 Döneminde 681 kooperatife 99 milyon TL kredi kullandırılmış iken, 2003-2017 döneminde kredi verilen kooperatif sayısını yaklaşık 3 kat, destek miktarını ise yaklaşık 22 kat arttırarak 2,2 milyar TL ile 1.858 kooperatif destekledik" bilgisine yer vermektedir. Türkiye'de kırsal kesimin önemli bir kısmını oluşturan orman köylerinde bulunan kooperatiflere sağlanan destekler ise $A K$ Parti'nin seçim beyannamesinde yer alan bilgilerden farklılık göstermektedir. Orman Genel Müdürlüğü’nün resmi rakamlarına göre; 1990-2002 y1lları arasında 412 kooperatife 187 milyon TL destek verilmişken 2003-2017 yılları arasında 195 kooperatife 52 
milyon TL destek sağlanabilmiştir (OGM, 2018). Seçim beyannamesindeki bilgilerin aksine $A K$ Parti iktidarda olduğundan beri hem desteklenen ormancılık kooperatifi sayısında hem de destek miktarında bir azalış olmuştur. Atmiş ve Günşen (2013) de AK Parti hükümetlerinin orman köylerine sağlanan desteklerde kooperatifler yerine bireylerin desteklenmesinin ağırlık kazandığını tespit etmiştir. AK Parti seçimden sonraki dönem için kooperatiflere sağlayacağı destekle ilgili bir beyanda bulunmamaktadır. $C H P$ ise iktidara gelirse, orman köylülerine hem bireysel hem de kooperatif bazında destek veren ORKÖY'ün kredilerinin hibe oranını artırarak, kredi ödeme koşullarını iyileştireceğini beyan etmektedir.

CHP bildirgesinde ormancılık kooperatifleriyle ilgili olarak AK Parti'ye göre daha fazla beyana yer vermektedir. Orman köyleri gibi kırsal kesimde bulunan yerleşimlerde demokratik bir yapı olan kooperatiflere önem gösteren CHP "Orman köylerinde kooperatifleşmeyi teşvik edeceğiz. Kooperatiflerin veya üst kuruluşların kendi bünyelerinde Sosyal Yardımlaşma Fonları'nı geliştirecek ve destekleyeceğiz.” beyanında bulunmaktadır. Diğer taraftan "Orman içi ve civarında yaşayan orman köylüsüne ve kooperatiflerine ormancılık faaliyetlerinde öncelik vereceğiz." vaadinde bulunan CHP aslında 6831 sayılı Orman Kanunu'nun yürürlükte olan 40. maddesinden bahsetmektedir. Orman Genel Müdürlüğü odun ve odun dışı orman ürünlerinin üretimini vahid-i fiyat (birim fiyat) ile ormancılık kooperatiflerine yaptırabilmektedir. Ancak birim fiyatın belirlenmesinde ormancılık örgütü ile ormancılık kooperatifleri arasında anlaşmazlıklar olabilmektedir (Atmiş vd., 2009). CHP bildirgesinde, birim fiyat belirlenmesinde ormancılık kooperatif birliklerinin görüşlerini dikkate alarak katılımcı bir şekilde sorunu çözeceğini beyan etmektedir. CHP bildirgesinde orman köylülerinin sosyal güvenliğe ve emeklilik haklarına sahip olmadan çalıştıklarını belirterek ormancılıkla ilgili işlerde çalışan orman köylülerini sosyal güvence altına alıp, sigorta primlerinin devlet tarafından ödenmesini sağlayacaklarını beyan etmektedir. Ayrıca $\mathrm{CHP}$ "Orman işlerinde iş sağlığı ve güvenliği konusunda devleti işveren statüsünde sorumlu” tutacaklarını da ifade etmektedir.

Toplumun en düşük gelir seviyesine sahip grubu olan orman köylülerini her açıdan desteklemek isteyen $C H P$ bildirgesinde "Orman içi boşlukların orman ekosistemini bozmadan orman köylüsünün tarımsal amaçlı kullanımına bedelsiz olarak açacağız." beyanında bulunmaktadır. Orman içi açıklıklar orman ekosisteminin bir parçasıdır ve özellikle yaban hayvanlarının yaşamlarında önemli noktalardır. Dolayısıyla orman içi açıklıklarda yapılacak tarımsal faaliyetler mutlak suretle orman ekosistemine zarar verecektir. $\dot{I P}$ "Ormanlarını koruyan her köyün kendi sınırlarındaki ormanlardan yararlanmasını sağlayacağız." beyanında bulunurken $M H P$ de orman köylüsünün desteklenmesinden bahsetmekte, fakat her iki parti de bunun nasıl olacağını dile getirmemektedir.

Seçimlerden sonraki dönemde koruma ve kullanma dengesini gözeten bir anlayışla politika üretmenin ve doğal kaynakları sürdürülebilir bir anlayışıyla yönetmenin temel hedefi olacağını belirten $A K$ Parti "Yeşil Ekonomi, yeşil büyüme, yeşil istihdam gibi kavramları sürdürülebilir kalkınma hedeflerimiz arasında değerlendireceğiz." beyanında bulunmaktadır. Beyannamesinde sürdürülebilir kalkınmanın ancak kırsal üretim ve koruma ile mümkün olacağının bilincinde olduğunu söyleyen $A K$ Parti, kırsal nüfusun temel ve altyapı ihtiyaçlarını karşılayarak kırsal alanda üretken bir biçimde yaşamasını sağlamayı amaçlamaktadır.

Kırsal kalkınmayı şehirlerin ve ülkenin beslenmesinde temel girdiler sağlayan, bulunduğu çevreye değer katan bir olgu olarak değerlendiren $A K$ Parti kırsal kesimde yaşayanlara temel hizmetlerin ulaştırılmasının, yaşam kalitelerinin artırılmasının ve kırsal yaşamın korunarak geliştirilmesinin temel öncelikleri arasında olduğunu da ifade etmektedir. İktidarı döneminde Cumhuriyet tarihinin en büyük kırsal altyapı hamlesini başlattığını iddia eden $A K$ Parti, kırsal kalkınmada yönetişimi güçlendirdiğine, idari kapasiteyi geliştirdiğine, Ulusal Kırsal Kalkınma Stratejisi ile Kırsal Kalkınma Planı'nı hazırladığına değinmektedir. Ayrıca KÖYDES, KIRDES ve BELDES projeleriyle kırsal alanlarda alt yapı çalışmalarını yürüttüğünü ve Avrupa Birliği ile diğer uluslararası kuruluşlardan temin edilen fonlarla kırsal alanın desteklenip istihdamın arttırıldığını bildirmektedir. Seçimleri kazandığı takdirde bu çalışmalara devam edeceğini bildiren $A K$ Parti, ayrıca kırsal kalkınma desteklerini tüm illere yayacağını, kırsal nüfusun bulunduğu yerde tutundurulması için tarım-gıda işletmelerini yaygınlaştıracağını, kadınların ekonomik fırsatlara erişimi ve kalkınma sürecine uyumunu geliştireceğini ve kırsal alanlarda göçü önlemek üzere 4-5 köye ortak hizmet sunacak bölgesel yaşam merkezleri (spor alanları, eğlence merkezi, restoran vb.) oluşturacağını beyan etmektedir. AK Parti ayrıca üniversitelerde "kırsal kalkınma" alanında lisansüstü eğitim programları oluşturacağını da vaat etmektedir.

Kırsal kalkınma konusunda $M H P$ daha genel bir ifade ile "kırsal kesimde yaşayan insanlarımızın refah seviyesini artırmak için kırsal kalkınma projeleri kapsamında köy kalkınma planları yapılmalı, gelişme eğilimi yüksek olan köylerimizin "çekim merkezi” hâline gelmeleri sağlanmalıdır." demektedir. MHP'nin seçim beyannamesinde kullandığı üslup/dil vaat vermekten ziyade 24 Haziran 2018 Genel Seçimi’nde Cumhur İttifakı çatısı altında hareket ettiği iktidar partisi $A K$ Parti'ye yol gösterici niteliktedir. 
Beyannamesinde kırsal kalkınmaya öncelik vereceğini belirten $S P$ "Kırsalda bölgesel kalkınmanın temelini sağlayacak istihdam alanları" oluşturacağını ve "Bölgeler arası dengeleri de gözeterek orta ölçekli kentlerin en az 80-90 km dışında alt yapısı tamamlanmış kırsal kalkınmaya ya da orta ölçekli sanayiye olanak verecek yerleşim bölgeleri, cazibe ve büyüme merkezleri kurarak, kalkınmada öncelikli illerin sayısını" arttıracağını vaat etmektedir. Ayrıca kırsal alanda herkesin kendi işinin sahibi olmasının sağlanacağını, kırsalda gelirin tabana yayılması için "yeni nesil kooperatiflerin” kurulmasına öncülük edeceğini beyan etmektedir. IP ise yeni bir kentsel idari yapılanmaya gideceğini ve bunda kırsal kalkınma hedeflerini de dikkate alacağını beyan etmektedir. Ancak beyannamesinde bu kırsal kalkınma hedeflerinin neler olduğuna değinmemektedir.

Ormancılık eğitiminin içeriği ve yöntemiyle direkt olarak ilgili olmamakla birlikte $A K$ Parti beyannamesinde yükseköğretimde ormancılık eğitimi gibi öncelikli alanda başarılı olan üniversite öğrencilerine YÖK-Lisans Bursları vermeye başladıklarına yer vermiştir. IP ise yükseköğretimde farklı bir konuya değinerek üniversite kampüslerini \%25 yeşil alan içermek üzere geliştireceğini beyan etmektedir. Üniversitelerin çalışma şekline değinen $H D P$ "Üniversiteleri demokratik, özerk ve çok kültürlü, toplum ve doğa yararına araştırma yapan kurumlar olarak yeniden inşa edeceğiz." beyanında bulunmaktadır.

2011 ve 2015 genel seçim beyannamelerinde okul bahçelerini ağaçlandırdığından bahseden $A K$ Parti, 2018 seçim beyannamesinde bu konuya yer vermemiştir. Ancak $C H P$ okullarda yeşil alanlar oluşturacaklarını, $H D P$ eğitim sistemini toplum ve doğayla bütünleşik, ekolojik perspektifi temel alarak yeniden yapılandıracağını ve $\dot{I} P$ öğrencilerin kişisel gelişimlerine önemli katkı yapacağını düşündüğü bilim merkezleri, müzeler, botanik bahçeleri gibi bilimsel, sosyal ve kültürel mekânların sayılarını artıracağını, bunların öğrenme alanları olarak etkin kullanımını sağlayacağını beyan etmektedir. Müzelerle ilgili olarak AK Parti ise; seçilen şehirlerde Milli Doğa Tarihi Müzesi ile Botanik Müzesi gibi tematik müzeler kuracağını beyan etmektedir.

\subsection{Politika ve Mevzuat Değişikliği}

AK Parti 2002 yılında iktidara gelmesiyle birlikte çevre politikalarında ve uygulamalarında Türkiye'de yeni bir dönemi başlattığını iddia ederek "çevreyi koruma, her türlü kirliliği giderme, ağaçlandırma, yenilenebilir enerji ve enerji verimliliği, tarım topraklarının korunması ve içme suyuna erişim alanlarında önemli adımlar" attığını bildirmektedir. SP ise "Çevre koruma politikalarında, vatandaşlarla ve tüm ilgili sektör ve sivil toplum kuruluşları ile ortak hareket edilmesine özen gösterilecek, sorunların çözümünde katılımcı yollarla bütünleşmiş çözümlere ulaşılacaktır." beyanında bulunurken, ayrıca "Çevrenin korunmasında yerel yönetimlerin sorumluluklarının artırılmasına yönelik yasal düzenlemeler yapılacağını” da bildirmektedir.

MHP seçim beyannamesinde, benimsediği çevre politikasının temelinin Anayasa'nın 56. Maddesine dayandığını belirtmektedir. Ancak MHP beyannamesinde vaat vermekten ziyade ülkede nasıl bir çevre politikası benimsenmesi gerektiği yönünde bir üslup kullanmaktadır. Buna MHP'nin beyannamesinde yer alan 'çevre sorunlarını; kalkınma-çevre koruma ikilemi yerine, akılcı bir koruma, kullanma ve geliştirmeyi öngören sürdürülebilir kalkınma modeli ile aşarak, gelecek nesillere temiz, doğal ve kültürel değerleri korunmuş, yaşanabilir bir çevrenin intikalini sağlayacak politikalar hayata geçirilmelidir.” ifadesi örnek gösterilebilir.

Bazı siyasi partiler hedeflediği ekonomi politikalarında doğayı da göz önünde bulundurmaktadır. Doğaya saygılı bir parti olduğunu ifade eden CHP "Enerjiyi akılcı kullanan, doğayla barışık bir kalkınma ve refah programını" benimseyeceğini bildirmektedir. Ayrıca, doğa dostu politikaları büyümenin önünde bir engel olarak değil, hızlı ve kalıcı büyüme için bir firsat olarak gören $C H P$ düşük karbonlu sektörlere, yeşil teknolojilere, yenilenebilir enerji kaynaklarına, enerji tasarrufuna dönük malzeme ve teknolojilere yatırımda öncelik tanıyacağını ifade etmektedir. Doğa ile uyumlu bir ekonomi bakışı olduğunu dile getiren HDP ekonomi politikalarının yeşil çizginin tüm canlıların ekolojik hakları olduğunu ve doğa dostu bir ekonomi programı benimseyeceğini vaat etmektedir. $M H P$ ise Türkiye'nin sahip olduğu doğal kaynakların ülkenin gelişmesinde ve kalkınmasında önemli firsatlar sunduğunu, bu yüzden bu doğal kaynakları dikkate alan bağımsız ve milli bir "Üreten Ekonomi Programı"nı hedeflediklerini beyan etmektedir. Ayrıca, MHP seçim beyannamesinde ortaya koyduğu enerji politikalarının temel hedefleri arasında; "Çevreye dost ve duyarlı bir anlayışla, gelişmiş atık kontrol ve bertarafina, havza ve kaynak planlamasına dayalı bir yaklaşımla enerjinin çevre ve insan sağlığına zarar vermeden üretilmesi” hedefi yer almaktadır.

Ekonomi politikalarının dışında, CHP son dönemde Orman Kanunu'nda orman köylüsü aleyhine yapılan değişiklikleri kaldıracağını beyan ederken, bu olumsuz değişikliklerin neler olduğunu ve bunları nasıl gidereceğini bildirgesinde açıklamamaktadır. IP ise sürdürülebilir yaşayan kentler başlığı altında korumayla ilgili olarak "Doğal çevre ile bir bütün olan yerler (Kapadokya, arkeolojik sitler, ören yerleri vd.) için daha duyarlı ve 
özel bir yönetim modeli" uygulayacağını ve bunun için de "Koruma ile ilgili yasal, yönetsel ve idari bir reform" yapacağını beyan etmektedir.

12 Haziran 2011 tarihindeki genel seçimlerin ardından ormancılık örgütünün yeniden yapılandırılmasıyla birlikte daha önce direkt olarak bakanlı̆̆a bağlı olan ormancılık araştırma enstitüleri Orman Genel Müdürlüğü’ne bağlanmıştır. Ormancıllk örgütünün yönetim yapısındaki bu değişikliğgin çeşitli sorunları da beraberinde getirdiği dile getirilmektedir (Coşgun, 2015). CHP seçim bildirgesinde "Orman Araştırma Enstitüleri'ne yeniden işlevsellik kazandıracağız.” beyanında bulunarak bu sorunu çözeceğini ifade etmektedir.

\subsection{Plan Proje ve Kadastro Çalışmaları}

Seçime giren partiler arasında orman amenajmanı konusuna değinen tek parti $S P$ olmuştur. $S P$ beyannamesinde "Orman amenajman (düzenleme) planları hazırlanarak uygulanacaktır." demektedir. Oysa Türkiye'de 1917 yılında devlet ormanlarının 1924 yılında ise ülkedeki tüm ormanların amenajman planlarıyla işletilmesi esası kanunla kabul edilmiştir (Özdönmez vd., 1996). Yani bu vaat yeni bir uygulamadan bahsetmemektedir.

Beyannamesinde çevre dostu şehirler geliştireceğine değinen $A K$ Parti bunun için "Yeşil Sertifika Sistemi ile sürdürülebilir yeşil binaların ve yerleşmelerin sertifikalandırılmasını sağlayacağız. Yeni bir 'yeşil kamusal alan planlama anlayışı' oluşturacağız. Bina ölçekli yeşil alan uygulamalarından bağımsız olarak, mahalledeki bina yoğunluğuyla orantılı büyüklüklerde aktif yeşil alanlar oluşturacağız. Mahalle ölçeğinde 'ağaç envanteri' belirleyerek, periyodik olarak izleyeceğiz." vaatlerinde bulunmaktadır. AK Parti ayrıca "Şehrin farklı kesimlerinin ortak kullanım alanları olan kamusal açık ve yeşil alanlar ile şehir parkları, meydanlar gibi mekânsal düzenlemelerin sayısını ve niteliğini” arttıracağını ve "Mekânsal Planlar Yapım Yönetmeliği ile il bütününde kişi başına 10 metrekare olan yeşil alan şartını, 15 metrekareye çıkarttığını" bildirmektedir. Benzer şekilde $V P$ de seçim bildirgesinde büyük kentlerde yeşil alanların artırılacağı, yeni parklar ve oyun alanlarının açılacağı beyanlarında bulunmaktadır.

AK Parti'nin önceki seçim dönemlerinde beyannamelerinde dile getirdiği "kalkınma projelerine" bu seçim beyannamesinde de yer verdiği görülmektedir. Bunlardan biri kent içi yeşil alanları arttırmaya yönelik olan İstanbul'da 30 Yeşil Alan ve Beş Büyük Millet Bahçesi Projesi'dir. Bu projeyle AK Parti, yeni havalimanının hizmete girmesiyle birlikte Atatürk Havalimanının tamamını Millet Bahçesi haline dönüştürmeyi planlamaktadır. Ayrıca bu büyük projeyle İstanbul'un farklı yerlerinde toplam 11,4 milyon $\mathrm{m}^{2}$ 'lik 30 yeşil alan projesinin ve Başakşehir, Maslak, Pendik ve Bakırköy'de toplam 1,4 milyon $\mathrm{m}^{2}$ büyüklüğünde şehir parkı projelerinin tamamlanacağı beyanında bulunmaktadır. İstanbul dışında Eskişehir, Bursa, Trabzon, Gaziantep, Adana ve Mersin başta olmak üzere, ülke genelinde "Millet Bahçeleri Projesi”nin hayata geçirileceği AK Parti'nin seçim beyannamesinde yer almaktadır.

CHP bildirgesinde "Bölge, havza ve kent-kır ölçeğinde bütünleşik planlama anlayışı geliştireceğiz." vaadinde bulunmaktadır. Beyannamesinde insan ve çevre arasındaki ilişkileri doğa ile uyumlu hale getireceğinden bahseden $\dot{I} P$ kentsel mekanları ekolojik planlamayı göz önüne alarak planlayacağına da vurgu yapmaktadır. Anayasa'nın 56. Maddesi ile garanti altına alınan "herkesin, sağlıklı ve dengeli bir çevrede yaşam hakkına" değinen $S P$; çevreci, doğal dengeyi koruyan, iklim dostu belediyeler oluşturulacağını, yeni şehirlerin inşasında doğal ve tarihi dokusunun bozulmayacağı vaadinde bulunmaktadır. $M H P$ ise "yerleşimlerin afete duyarlı olması, doğal, tarihi ve kültürel varlıkları koruması ve yaşatması, kentlilik kültürünün oluşturulmasına katkı sağlaması, su kaynaklarının ve çevrenin korunması, planlı, çağdaş altyapılı yaşanabilir kentler inşa edilmesi, yerel kalkınmanın sağlanması, hizmetlere erişimin kolaylaştırılması ve kentte yaşayan vatandaşın hayat kalitesinin artırılmasını" amaçlayan bir kentleşme politikası benimsediğini ifade etmektedir. $A K$ Parti, $C H P, \dot{I} P, S P$ ve $M H P$ bildirgelerinde, şehirlerin özellikle yeşil alt yapı açısından planlanmasından bahsetmektedir. Ancak şehirlerde yaşayanların bu süreçlere katılımına hiç değinmemektedirler. Oysa Tosun ve Tosun (1995: 63) kentsel alanları düzenleyen imar ve kent planlarının siyasal iktidarlara göre değişmesinin önlenerek, rasyonel ve kent halkının katılımını sağlayacak şekilde düzenlenmesi gerektiğine vurgu yapmaktadır.

$\dot{I P}$, Ergene Havzası gibi ekolojik dengenin bozulduğu yerlerde rehabilitasyon eylem planları yapıp uygulayacağını ve maliyetleri karşılamada kirletenlerin ve izin verenlerin katkısının zorunlu kılınacağını bildirmektedir. Kent meydanlarının, parkların, koruların ve kıyıların korunacak ortak alanlar olduğunu belirten $H D P$ bu alanların kamusal, doğal niteliğini ve kültürel dokusunu bozacak, ekolojik yıkıma yol açıp tahrip edecek sermaye projelerine ve uygulamalarına izin vermeyeceğini beyan etmektedir. AK Parti'nin 2011 genel seçim beyannamesinde yer verdiği "Kanal İstanbul" projesine de atıfta bulunan $H D P$, Kanal İstanbul gibi projelerin tümü başlatılmış olsa dahi durdurulacağını ve "Çılgın projeler" yerine insan, toplum ve doğa yararına makul projeler gerçekleştirerek herkese insan onuruna yakışır barınma imkânı sağlayacağını vaat etmektedir. 
AK Parti, ülkedeki sel, çı̆̆ ve heyelan olaylarının önlenmesi için 2023 yılına kadar 25 adet Çı̆̆ Kontrol Projesi ve Çı̆̆ Tehlike Haritası, 35 adet Heyelan Kontrol Projesi ve Heyelan Tehlike Haritası, 250 adet alanda sel kontrol projesini hayata geçireceğini beyan etmektedir.

Orman kadastrosuyla ilgili olarak AK Parti 2019 yılı sonuna kadar ülke ormanlarının tamamının tapu ve tescil işlemlerini gerçekleştireceğini, $S P$ ise orman alanlarının kadastral verilerinin uydudan takibini sağlamak için Orman Alanları Takip Sistemi kuracağını beyan etmektedir.

\subsection{Ormanculık Hizmetleri ve Korunan Alanlar}

AK Parti iktidara geldikten hemen sonra 2003 yılında başlattığı şehir (kent) ormanı projesiyle, bu güne kadar 140 şehir (kent) ormanı kurup, mesire yerlerinin sayısını ise 1313'e çıkardığını ifade etmektedir. AK Parti seçim beyannamesinde şehir (kent) ormanlarının sayısını 2019 yılına kadar 160'a çıkaracağını vaat ederek, şehir (kent) ormanlarının da içinde bulunduğu mesire yerlerinin sayısını 2023 yılına kadar 2.000'e çıkarmayı hedeflediğini bildirmektedir. Başta kent ormanları olmak üzere mesire yerleri özellikle kentli nüfusun rekreasyonel faaliyetlerde bulunabilmeleri için önemli alanlar olmasına rağmen, AK Parti bu alanların sadece sayılarıyla ilgilenmiştir. Bu alanların oluşturulmasında halkın beklentileri, çeşitli ilgi gruplarının katılımı ve alanın niteliği göz ardı edilerek sadece politik kararlar etkili olmaktadır (Atmiş, 2016).

2015 genel seçim beyannamesinde e-devlet projelerinden birisi olan Orman Bilgi Sistemi (ORBİS) Projesini tamamladığını 2018 beyannamesinde dile getiren $A K$ Parti, ORBİS ile bütüncül olarak ormanlara dair tüm verilere hızlı bir şekilde ulaşılabildiğini bildirmektedir. Ormanların korunması için aktif mekanizmaları harekete geçirdiklerini dile getiren $A K$ Parti "Kurduğumuz yangın erken uyarı sistemi ile yangınlara müdahale süresini, 45 dakikadan ortalama 15 dakikaya düşürdük. Bu sayede yanan alanları geçmiş yıllar ortalamasının dörtte birine indirdik." bilgisini beyannamesinde paylaşmaktadır. Fakat Ak Parti hükümetinin dönem dönem basın açıklamalarında ve raporlarında da kullandığı orman yangınlarının verdiği zararı azaltma konusunda başarılı oldukları hakkındaki beyanlarının doğruluğunun sorgulanması gerektiği de ifade edilmektedir (Atmiş ve Günşen, 2018a).

Doğal kaynakların yönetilmesi ve kullanımı konusunda iktidar partisi olan AK Parti'yi sert bir dille eleştiren CHP, AK Parti'nin “doğrudan kamu eliyle, kamu özel sektör ortaklığıyla ya da özel sektörün önünü açarak doğa katliamlarına imza" attı̆̆ını söylemektedir. Ayrıca, inşaat, madencilik, enerji, ulaştırma, sanayi ve tarımda $A K$ Parti politikalarının ekosistemlere geri dönülemez zararlar verdiğini ve $A K$ Parti’nin kaynakların aşırı tüketimi ile kırılgan kesimlere zarar vererek gelecek kuşaklara karşı sorumlulukları hiçe saydığını iddia etmektedir.

CHP bildirgesinde "Zarar gören doğal yaşam alanlarını ve soyu tükenme tehlikesi altındaki türleri etkin bir şekilde” koruyacağını beyan etmektedir. Ayrıca, doğal kaynakların usulsüzlük ve siyasal çıkar aracılığıyla ticari rant sağlama alanına dönüştürülmesine engel olacağını bildiren $C H P$, doğayı insanın mülkü olarak gören, doğal kaynakları sınırsızca ve sorumsuzca tüketen politikaları reddettiğini, doğanın korunmasını ve çevre sorunları ile mücadeleyi tüm insanların görevi olarak kabul ettiğini, daha adil ve eşit bir toplum inşa etmenin ön koşullarından birinin doğayı korumak, yeşil adaleti sağlamak olduğunu ifade etmektedir.

Tarım arazileri, doğal ve kültürel kimlikler ile yeşil alanların titizlikle korunacağı vaadinde bulunan $S P$, doğal kaynakların korunmasından ve onların sürdürülebilir kullanımından insanların sorumlu olduğuna vurgu yapmakta, doğal kaynakların özellikle de doğal ekosistemlerin korunmasında katılımcı planlama ve yönetimin benimsenmesi gerektiğini ifade etmektedir. VP ise seçim bildirgesinde "Ormanlar, kıyılar, bitki türü zenginliği, yabani hayvan varlığı korunacaktır. Bu değerler, özel çıkarcılığın neden olduğu yıkımdan kurtarılacaktır. Özel çıkarcılığın derelerimizi, ırmaklarımızı, körfezlerimizi, denizlerimizi ve toprağımızı kirletmesine ve yaşam ortamını bozmasına izin vermeyeceğiz. İnsan ile doğa arasındaki uyum ve dengeleri gözeteceğiz." vaatlerinde bulunmaktadir.

Kapitalizmin doğayı, kültürel ve doğal varlıkları ve yaşamı metalaştırarak sömürmesine karşı ekosistemi korumanın temel ilkeleri olduğunu ifade eden HDP, iktidara gelirlerse Anayasa'ya "doğa hakları insanların çıkarlarından üstündür" anlayışını yerleştireceğini beyan etmektedir. Ayrıca HDP seçim bildirgesinde "Ormanların, derelerin, havanın, suyun, taşın, toprağın, ağacın, kurdun, kuşun, böceğin, tüm yaşamın haklarını koruyarak, yaşamın bilgisini savunacağını" vaat etmektedir. IP ise "Çevrenin doğal kalması ve sağlıklı olmasını doğanın hakkı sayarak sıkıca korunacağını taahhüt" ettiğini ve "Doğal ve tarihsel çevre korumasına ilişkin yerel ve merkezi yönetime ayrılan bütçe paylarını” artıracağını bildirmektedir. 
AK Parti 2002 yılında iktidara gelmesiyle birlikte çevre politikalarında ve uygulamalarında yeni bir dönem başlattığını ve bu çerçevede orman ve korunan alanların genişletilmesi ve biyolojik çeşitliliğin korunması ile ilgili uygulamalara öncelik vererek, çevresel göstergeleri iyileştirdiğini söylemektedir. Ayrıca, biyolojik çeşitliliğe dayalı geleneksel bilginin kayıt altına alınması projesini 12 ilde pilot olarak başlattığını ve Ulusal Biyolojik Çeşitlilik Envanteri projesini 54 ilde tamamladığını bildirmektedirler. AK Parti, bu iki iddialı projeden Ulusal Biyolojik Çeşitlilik Envanteri projesini 2019 yılına, biyolojik çeşitliliğe dayalı geleneksel bilginin kayıt altına alınması projesini ise 2023 yılına kadar tüm illerde tamamlayacağını iddia ederek Çukurova Biyolojik Çeşitlilik Müzesini de hizmete açacağını ifade etmektedir.

2002 yılından beri iktidarda olması, AK Parti'ye seçim beyannamesinde genel seçimlerin öncesindeki dönemde neler yaptığını anlatma imkânı yaratmıştır. $A K$ Parti beyannamesinde korunan alanlarla ilgili yaptıklarını, daha çok niceliksel olarak halka aktarmayı seçmiştir. Bu, beyannamesinde yer alan "Ülkemizdeki korunan alanların (Doğal sit, Özel Çevre Koruma Bölgesi, Milli Park, Tabiat Parkı, Tabiatı Koruma Alanı, Tabiat Anıtı, Yaban hayatı Koruma Sahası ve Sulak alan) toplam yüzölçümüne oranını yüzde 4,34'ten, yüzde 12,68'e çıkardık. Son 16 yılda korunan alanların sayısını 175 'ten 558'e yükselttik. Alan olarak ise 9,3 milyon dekardan 30 milyon dekara çıkarttık. Özel Çevre Koruma Bölge sayısı 2002 yılında 13 iken, bugün 16’ya çıkardık.” bilgilerinden açıkça anlaşılmaktadır. Beyannamesinde doğal alanların korunmasına azami önem verdiğini iddia etmesine karşın AK Parti'nin iktidarda olduğu zaman zarfında korunan alanların statü değişiklikleri, sınırlarının yeniden düzenlenmesi, madencilik ve turizm faaliyetlerine tahsis edilebilir hale getirilmesi sıklıkla gündeme gelmiş ve korunan alanlarda korumadan ziyade kullanmanın ağırlık kazandığı dile getirilmiştir (Atmiş, 2018).

Ayrıca AK Parti beyannamesinde korunan alanlarla ilgili diğer yaptıklarını da şu şekilde belirtmiştir: "Ekolojik Temelli Bilimsel Araştırma Raporları yaptırarak, ülkemizdeki doğal sit alanlarının doğal değerlerinin güncel durumlarını ortaya çıkardık. Korunan alanlarda gerçekleştirilen projeler için yerel yönetimlerimize 400 milyon TL kaynak sağladık. Korunan alanlarımıza tabiat eğitim merkezleri, gençlik kampları gibi tesisleri kurarak tabiatın ve biyolojik çeşitliliğin korunmasına yönelik eğitim ve bilinçlendirme çalışmaları yürüttük. Korunan alanlarımıza yapılan yatırımlarla 2003 yılındaki 5,5 milyon ziyaretçi sayısını, 2017 yılında 25 milyon kişiye çıkardık. Kop Dağı Müdafaası Tarihi Milli Parkı ve Malazgirt Meydan Muharebesi Tarihi Milli Parklarını ilan ettik. Tarihi milli parklarımızda (Sakarya Meydan Muharebesi, Nenehatun, Sarıkamış ve Başkomutan Tarihi Milli Parkları) tanıtım merkezleri ve yönetim merkezleri kurarak şanlı tarihimizi gelecek nesillere aktarıyoruz.”

Ayrıca AK Parti seçim beyannamesinde milli parklar, tabiatı koruma alanları ve tabiat parklarına giriş indirimi sağlayarak ulaşımda ve iletişimde engelleri kaldırıp yaşamları kolaylaştırdıklarını iddia etmektedir. 2873 sayılı Milli Parklar Kanunu'na göre içinde sadece bilimsel araştırmalara müsaade edilen tabiatı koruma alanlarında giriş ücretinin düşürüldüğü ifadesinin kullanılması, AK Parti tarafından bu alanın rekreasyonel amaçlı kullanılan bir yer olarak algılandığını ortaya koymaktadır. Aynı yanılgıya AK Parti iktidarı döneminde her bir il için hazırlanan doğa turizmi gelişim planlarının bazılarında da düşüldüğü bildirilmektedir (Günşen ve Atmiş, 2017).

AK Parti seçim beyannamesinde korunan alanlarla ilgili şu vaatlerde bulunmaktadır: "Korunan alanlarda altyapı eksikliklerini gidereceğiz. Bu alanlarda gerçekleştirilecek projeler için yerel yönetimlerimize destek sağlayacağız. Korunan alanlarımıza, tabiat eğitim merkezleri, yaz okulu ve gençlik kampları tesis ederek tabiatın ve biyolojik çeşitliliğin korunmasına yönelik eğitim ve bilinçlendirme çalışmalarını yürüteceğiz. Ülkemizde korunan alanların sayısını 2023 yılı sonunda 653'e çıkaracağız. Yapacağımız altyapı, tanıtım vb. çalışmalarla 2023 yılına kadar korunan alanlarımızda toplamda 135 milyon ziyaretçi ağırlamayı hedefliyoruz. Korunan alanlar içinde yaşayan yöre halkının, gelirinin artırılmasına yönelik faaliyetlerin önünü açacağız. E-Devlet üzerinden tüm korunan alanların vatandaşlarımızla paylaşılabilmesi için, ulusal düzeyde doğal sit alanlarını sayısal hale getireceğiz."

Yaban hayatını koruyup ekosistemlerini güçlendirerek 81 yaban hayatı geliştirme sahasında yaban hayvanlarını doğal yaşama ortamlarıyla birlikte koruduklarını belirten $A K$ Parti, zorlu kış şartlarında yaban hayvanlarının hayatlarını idame ettirmeleri maksadıyla yemleme çalışmaları yaptıklarını, nesli tehlike altında olan türlerden öncelikli tespit edilen 60 hassas tür için eylem planları hazırladıklarını ve tabiatın desteklenmesi maksadıyla her y1l keklik, sülün gibi ortalama 100 bin kanatlı hayvan ve 3,7 milyon yavru alabalık üreterek tabiata bıraktıklarını, böylelikle yaban hayatını koruyup ekosistemleri güçlendirdiklerini iddia etmektedir. AK Parti seçim beyannamesinde yaban hayatının korunması ve desteklenmesi maksadıyla yaban hayvanı üretimi ve tabiata yerleştirilmesi çalışmalarını sürdüreceğini, kış aylarında yemleme çalışmalarına devam edileceğini, hassas türlerin koruma eylem planlarının tamamlanacağını beyan etmektedir. Ayrıca tabiatta zarar görmüş yaban hayvanlarının tedavi ve rehabilitasyonu için yaban hayatı kurtarma ve rehabilitasyon merkezleri kuracaklarını, zengin yaban hayatı kaynaklarını değerlendirmek ve ekonomiye kazandırmak amacıyla av turizmi geliştirme bölgeleri oluşturacaklarını bildirmektedir. 
Saadet Partisi, AK Parti dişında statüleriyle birlikte korunan alanlara değinen tek partidir. SP beyannamesinde "Korunan alanlarda (milli parklar, tabiatı koruma alanları, yaban hayatı geliştirme alanları, tabiat parkları, sit alanları, özel çevre koruma bölgeleri, tabiat varlıkları ve sulak alanlar gibi) kentleşmenin ve rant amaçlı tahribatın önüne geçilecektir." diyerek korunan alanlar üzerindeki kentleşme ve rant baskısını durduracağını beyan etmektedir. Diğer yandan SP ormanları koruma çalışmalarının devam etmesiyle birlikte mevcut ormanların ekolojik dengeler gözetilmeden yapılaşma, yol açma gibi faaliyetler ile yok edilmesinin kaygı verici olduğunu dile getirmektedir.

$C H P$ ve $H D P$ iktidar partisi olan $A K$ Parti'nin uyguladığı politikaların ekosistemlere geri dönülmez zararlar verdiğini ve doğal kaynakların talan edildiğini iddia etmektedir. CHP iktidara gelirse "Ormanlarımızı, meralarımızı, su kaynaklarımızı, denizlerimizi ve göllerimizi koruyacağız. Hayvan hakları alanında $A B$ standartlarını yakalayacak, yaban hayatının korunması ve geliştirilmesi için önlemler alacağız. Biyolojik çeşitliliğimizin ve endemik türlerin korunması için bu alana yoğunlaşmış özel enstitüler ve çeşitlilik bankaları kuracağız." vaatlerinde bulunmaktadır. VP ise seçim bildirgesinde "Doğal ve tarihi SíT alanlarının rant uğruna talan edilmesine, tarihi yerlerde yapılan restorasyon yanlışlarına son vereceklerini” bildirmektedir.

AK Parti kitle turizminin yanı sıra kültür turizmi, sağlık ve termal turizmi, kış turizmi, ekoturizm ve yayla turizmi gibi turizm türlerini öncelikli olarak ele alıp geliştireceğini ve Frigya, Kapadokya, Hitit, Troya, Aphrodisias, Söğüt, Göller Bölgesi ve GAP turizm bölgeleri başta olmak üzere kültür, termal ve doğa temalı turizm gelişim bölgeleri oluşturacağını beyan etmektedir. Doğa temalı ekoturizmin planlı gelişimini önemsediklerini belirten $A K$ Parti, ekoturizm bölgeleri ile diğer bölgeler arasındaki dengesizliklerin azaltılması ve kırsal alanlardaki göçün durdurulmasına katkıda bulunacağını beyan etmektedir. AK Parti ayrıca, "500 Yeşil Yıldız Belgeli konaklama tesisini ülkemize kazandırarak, sürdürülebilir turizm için çevre dostu turizm tesislerini” yaygınlaştıracağını, "Doğal ve kültürel kaynak potansiyeli yüksek yörelerde kırsal turizm altyapısını geliştirmeye devam" edeceğini vaat etmektedir.

\subsection{Ağaçlandırma, Özel Ormancılık ve Teşvikler}

AK Parti daha önceki seçim beyannamelerinde dile getirdiği gibi bu seçim beyannamesinde de iktidara geldiklerinden beri ağaçlandırmayla ilgili önemli adımlar atıldığını belirtmektedir. A ğaçlandırmada Türkiye'nin dünyanın en başarılı üç ülkesinden biri olduğunu iddia eden AK Parti, 4 milyar 50 milyon adet fidanı toprakla buluşturduğunu, ağaçlandırma ve orman ıslahı çalışmalarını ise 5 kat arttırdığını iddia etmektedir. Oysa Atmiş ve Günşen (2018a)'in OGM'nin resmi verilerini kullanarak yaptıkları çalışmada, 1989-2001 dönemde 522.373 ha alanda ağaçlandırma yapılmışken AK Parti'nin iktidarda olduğu 2003-2015 yılları arasında ormancılık örgütünün gerçekten ağaçlandırdığı toplam alanın yalnızca 472.052 ha olduğu ortaya çıkmıştır. Bu rakamlar, önceki 13 yıllık dönemde $A K$ Parti zamanından daha fazla ağaçlandırma yapıldığını kanıtlamaktadır. AK Parti’nin iktidarda olduğu zaman zarfında sadece özel ağaçlandırma miktarında ve orman sınırları içinde yapılan rehabilitasyon (1slah) çalışmalarında bir önceki döneme göre ciddi bir artış olmuştur. Diğer taraftan AK Parti, Baraj Havzaları Yeşil kuşak ağaçlandırmaları eylem planı ile bugüne kadar 400 adet baraj ve göletin etrafını ağaçlandırdığını ve buna devam edeceğini bildirmektedir.

Terk edilen maden sahalarıyla ilgili olarak $A K$ Parti, 43.000 dekar maden sahasını 1slah edip doğaya kazandırdığını ve terkedilmiş 60 bin dekar büyüklügünde 1.628 adet maden sahasını da 1slah ederek tabiata kazandıracağını vaat etmektedir. SP ise "Madencilik faaliyetleri sonucunda tabii halini kaybeden alanların doğaya yeniden kazandırılması için tarafların 'Peyzaj Onarım, Kapatma ve Rehabilitasyon Projesi' hazırlamasının zorunlu hale getirileceğini” bildirmektedir. Ancak bu projenin uygulamasının nasıl olacağı konusunda SP beyannamesinde hiçbir bilgi bulunmamaktadır.

Ağaçlandırma ve maden rehabilitasyon çalışmalarının dışında AK Parti "7 milyar insan, 7 milyar fidan" amacıyla Dünya'daki her insan için bir fidan dikerek 7 milyar fidanı toprakla buluşturacağı beyanında bulunmaktadır. Ancak, bu fidanların nerelere dikileceği ve nasıl bir çalışma olacağı konusunda ayrıntılı bir bilgi AK Parti’nin seçim beyannamesinde yer almamaktadır.

$V P$ seçim beyannamesinde "Erozyonu önleme ve ağaçlandırma için yoğun bir seferberlik gerçekleştireceğiz. Dağlarımız büyük bir ağaçlandırma seferberliği ile orman haline getirilecektir. Sadece bu ağaçlandırma kampanyası için 10 binlerce orman işçisi istihdam edilecektir." demektedir. VP orman işçiliğine değinen tek parti olmakla birlikte, ağaçlandırma çalışmalarından sonra bu işçilerin akıbetinin ne olacağı konusunda bir görüş bildirmemektedir. CHP de benzer şekilde seçim bildirgesinde "Türkiye'deki en kapsamlı ağaçlandırma seferberliğini örgütleyeceğiz." beyanında bulunmakta ancak ayrıntısından bahsetmemektedir. 
IP beyannamesinde "Ekolojik denge içerisinde, sürdürülebilir bir Orman Yönetim anlayışı ile çevre kirliliğinin, çölleşmenin ve erozyonun önlenmesi amacıyla; havza bazında toprak muhafaza ve endüstriyel amaçlı ağaçlandırma çalışmaları yapacağız, verimsiz orman arazilerinin tamamını verimli hale getireceğiz." vaadinde bulunmaktadır. Ayrıca, $\dot{I P}$ "Endüstriyel ağaçlandırma konusundaki araştırmaları destekleyeceğiz, ağaç ürünleri ve yeni ahşap malzemeleri konusunda yetkinlik geliştirilmesini sağlayacağız." beyanında da bulunmaktadır. İP endüstriyel ağaçlandırmada araştırma geliştirme çalışmalarına önem verirken $C H P$ ise "Orman ürünleri ihtiyacını karşılamak üzere yapılacak endüstriyel plantasyonlar için teşvikleri artıracağız.” diyerek teşviklerden bahsetmektedir.

Çölleşme ve erozyonla mücadelede Türkiye'nin lider ülkelerden birisi olduğunu ifade eden $A K$ Parti, beyannamesinde " 1970 'li yıllarda denizlere, göllere ve barajlara erozyonla taşınan toprak miktarı yılda 500 Milyon ton iken, 16 yılda yaptığımız çalışmalarla bu miktarı 2017 yılında 168 milyon tona düşürdük." bilgisine yer vermektedir. Bu konuda CHP de gerekli kaynağı sağlayıp erozyonla etkin olarak mücadele edeceğiz derken, "Kontrol altına alma oranını 5 yılda \% 25'e yükselteceğiz." beyanında bulunmaktadır. Ancak kontrol altına alma oranı hakkında bir bilgiye yer vermemektedir.

AK Parti beyannamesinde; ağaçlandırma çalışmalarında halkı teşvik etmek için "Ülkemizde orman alanlarını çoğaltmak, erozyonu önlemek, ceviz, badem, zeytin vb. ürünlerin üretimini desteklemek üzere 10 bin dönüme kadar Hazine taşınmazını gerçek ve tüzel kişilere kiralama amaçlı olarak arz edeceğiz." vaadinde bulunmaktadır. Fakat, bu tür ağaçlandırmaların orman kurmaktan çok, meyve bahçesi kurmaya yarayacağını gözden kaçırmaktadır.

\subsection{Orman ve Çevre}

Beyannamesinin farklı bölümlerinde kendisinden önceki dönemlerle karşılaştırma da yapan AK Parti, "19992002 yılları arasında 3 yılda sadece 9 tesis hizmete açılmışken, 16 yıllık dönemde 525'i baraj, 527'si HES, 336'sı gölet, 1.232'si sulama tesisi, 207'si içme ve kullanma suyu temini tesisi, 17'si atık su arıtma tesisi ve 4.640'1 taşkın koruma tesisi olmak üzere toplam 7.484 tesisi tamamlayarak Aziz Milletimizin hizmetine sunduk." söylemiyle ne kadar çok tesis kurduğunu halkın bilgisine sunmaktadır.

Ülkenin hidroelektrik enerji kurulu gücünü ilk iktidara geldiklerinden bu yana iki kattan fazla artırıp 27.502 MW'a yükselttiğini iddia eden $A K$ Parti hidroelektrik kapasitesine 10 bin MW'lık kapasite eklemeyi hedeflemektedir. AK Parti hidroelektrik enerji üretimini y1lda 26 milyar kWh'den 96,5 milyar kWh'e yükselttiklerini, böylece her 4 ampulden birini HES'lerden elde edilen temiz enerji ile aydınlattıklarını da beyannamesinde bildirmektedir. Oysa HES'lerde yenilenebilir bir doğal kaynak olan suyun kullanılmasına karşın, özellikle nehir tipi HES'lerin hem yapım aşamasında, hem de işletme aşamasında doğayı ve yöre halkını etkileyen birçok çevre sorununu da ortaya çıkarması HES'lerden elde edilen enerjinin ne kadar temiz enerji olduğunun sorgulanmasına da neden olmaktadır (Atmiş ve Günşen, 2018b).

Nitekim seçim bildirgelerinde HES'lerin elektrik üretiminden ziyade çevrelerine yaptıkları zararlara değinen partiler de bulunmaktadır. Bu konuda HDP "sermayenin çıkarı için yapılan baraj, HES, termik, nükleer vb. projelere, ekolojik yıkıma yol açan maden işletmeciliğine, endüstriyel atık ve kirlilik sonucunda yaşam alanlarının tahribine yol açan uygulamalara son vereceğiz" beyanında bulunurken diğer taraftan durumun sosyolojik boyutuna da dikkat çekerek "Sınır barajları ve HES projeleri ile kentsel dönüşümün neden olduğu yeni zorla göç ettirme politikalarına son vereceğiz" vaadinde de bulunmaktadır. $C H P$ ise "Uluslararası koruma altında olan alanlarda maden araması ve HES yapmayacağı" beyanında bulunarak elektrik elde etmek uğruna her yere HES yapmayacaklarını bildirmektedir.

$V P$ ülkenin enerji açığını kapatmak için doğayla uyumlu, güvenli, çağdaş ve milli teknoloji kullanan nükleer santraller kuracağını beyan ederken, $\dot{I} P$ ise enerji üretiminde daha genel bir dil kullanarak "Çevreyi kirleten ve tahrip eden enerji üretiminden vazgeçeceğiz. Sürdürülebilir temiz enerji üretim politikalarını uygulayacağız" beyanında bulunmaktadır.

Türkiye'de enerjinin kullanılmasında ortaya çıkan sera gazlarının yarattığı çevresel etkilerin de önemli bir sorun olduğunu dile getiren $V P$; bildirgesinde bu sorunun çözümüne ilişkin herhangi bir öneride bulunmamıştır. Çevrenin korunması ve iklim değişikliği ile mücadele kapsamında küresel sorunlara duyarsız kalmadığını dile getiren $A K$ Parti ise küresel iklim değişikliğiyle mücadele kapsamında $A K$ Parti hükümetleri olarak 2004 yllında Birleşmiş Milletler İklim Değişikliği Çerçeve Sözleşmesine ve 2009 yllında Kyoto Protokolü'ne taraf olunduğunu, 2016 yılında ise Paris Anlaşmasını imzalandığını beyannamesinde belirtmektedir. Ancak, imzalanan bu anlaşma Türkiye'ye gelişmiş ülkeler gibi finansal destek verme yükümlülüğü uygulandığı gerekçesiyle 
TBMM'den henüz geçirilmemiştir. Dolayısıyla Paris Anlaşmasının Türkiye için yasal bir bağlayıcılığı bulunmamaktadır. Ayrıca AK Parti, hükümet olarak 2011 yılında iklim değişikliği ile mücadele kapsamında Ulusal İklim Değişikliği Stratejisi ve İklim Değişikliği Eylem Planı’nı da hazırlamıştır.

"Küresel ısınmaya" neden olan sera gazı emisyonlarının kontrolüyle ilgili uygulamalara öncelik verdiğini ve çevresel göstergelerini iyileştirdiğini ifade eden $A K$ Parti "Ülke olarak küresel iklim değişikliği ile mücadele için 2030 yol haritamızı belirledik. Hızla gelişen bir ekonomi olarak sera gazı emisyonlarını 2030 yılında yüzde 21 'e kadar artıştan azaltmayı" hedeflediğini ve bu hedefi enerjiden ulaştırmaya, sanayiden kentsel dönüşüme, atık yönetiminden ormancılığa kadar tüm alanlarda yapacağı vizyon projeleriyle gerçekleştirmeyi planladığını belirtmektedir.

Ayrıca iklim değişikliğinin olumsuz etkilerinin mümkün olan en düşük seviyeye indirilmesi doğrultusunda çalışmalar gerçekleştirdiğini belirten $A K$ Parti, iklim dostu ve uzun vadeli düşük emisyonlu kalkınma stratejilerini yaygınlaştıracağını, sera gazı emisyonlarını başta karayolu olmak üzere tüm ulaşım türlerinde önlemeye yönelik çalışmalara öncelik verip ve gerekli takip sistemlerini kuracağını vaat etmektedir.

Türkiye'nin iklim değişikliği ile mücadelede $A K$ Parti iktidarında başarısız olduğunu belirten $C H P$, son 15 yılda enerji yoğunluğu ve fosil yakıt kullanımının arttığına vurgu yapmaktadır. Ayrıca CHP, "aşırı iklim olayları ile mücadele etmek için gereken altyapı çalışmalarının yapılmadığını" ve "kontrolsüz nüfus artışını destekleyen politikalar ile iklim değişikliğinin ülkemizde yaratacağı olumsuz etkileri daha da arttığını" bildirgesinde dile getirmektedir.

İklim değişikliğinin günümüzde dünyanın karşı karşıya kaldığı en büyük sorunların başında geldiğine dikkat çeken $C H P$, bu sorundan en çok etkilenecek ülkeler arasında Türkiye'nin de bulunduğunu bildirmektedir. İklim değişikliğiyle mücadelede $C H P$, öncelikle sorunun ciddiyetini tüm halka anlatabilecekleri bir farkındalık projesini hayata geçirmeyi hedeflemektedir. İklim değişikliği ile mücadelede, bu alanda öncü olan tüm dünya devletleri ile iş birliği içinde hareket edeceğini bildiren $C H P$, "bir yandan kamu politikalarını iklim değişikliği ile mücadele doğrultusunda yeniden yapılandırırken, diğer yandan özel sektörün regülasyonunu anayasal güvence altına alacağını" beyan etmektedir. CHP ayrıca "İklim değişikliğinin, Türkiye'de yaratacağı etki, kırılganlık ve riskleri inceleyecek ve bu kapsamda uyum stratejileri” ve doğa dostu üretim için "Tarım sektöründe iklim değişikliği etkilerine karşı uyum stratejisi” geliştireceğini beyan etmektedir. CHP, Anayasa ve mevzuatta iklim değişikliğine neden olan sera gazı salınımını azaltmaya yönelik sınırlayıcı düzenlemeler yapacağını da bildirmektedir.

$S P$ iktidara geldiğinde, iklim değişikliğinde insan kaynaklı etkiyi yönetmek ve en aza indirmek için belediyelere "Karbon Yönetimi Eylem Planları" hazırlayacağını ve kuracakları İklim Değişikliğini İzleme Merkezleri ile iklim üzerine olumsuz etkileri bulunan faktörleri en aza indireceklerini beyan etmektedir. İklim değişikliğinin ekonomik, sosyal, coğrafi ve doğal etkilerine göre mücadele hedefleri belirleyeceğini ifade eden $\dot{I P}$, iklim değişikliğinin ulusal ve bölgesel olarak ekonomik ve sosyal etkilerini tespit edeceğini bildirmektedir. Ayrıca $I P$ iklim değişikliğiyle ilgili olarak "Sanayi, enerji, tarım, çevre ve eğitim politikaları, yatırım teşvikleri, dış ticaret, yerel yönetimler ve bölgesel kalkınma hedefleri ile bütünleşmiş bir ulusal eylem planı hazırlayacağız” beyanında da bulunmaktadir.

Beyannamesinde çevresel etki değerlendirmesi (ÇED) süreçlerini basitleştirdiğini belirten AK Parti bu kapsamda "işlemleri elektronik ortama aldık ve mevzuatta yapılan düzenlemelerle bürokrasiyi azalttık, yatırım ortamını iyileştirdik" ifadesini kullanmaktadır. AK Parti, gelecek dönemde ÇED süreçlerinin daha etkin uygulanmasını sağlayacağını ve Ulusal Çevre Etiketleme Sistemini kurarak, ürün ve hizmetlerin çevreye duyarlılığını belirleyeceğini beyan etmektedir.

ÇED denetimleri ve raporlarında kamusal çıkarları gözeteceğini ifade eden $C H P$, ÇED raporlarının uzmanlar tarafından şeffaf biçimde, çevre koruma bilinci ve kaygısıyla hazırlanmasını sağlayacağını beyan etmektedir. CHP, ÇED'in yanı sıra kapsamlı bir Sosyal Etki Değerlendirmesi (SED) sürecini de başlatacaklarını ve hem ÇED hem de SED süreçlerinde yargı denetimini etkin kılacağını beyan etmektedir. Ayrıca, CHP bildirgesinde "Karayolu yatırımlarının yeniden ÇED kapsamına alınmasını sağlayacak yasal düzenlemeleri” yapacağını da vaat etmektedir.

$S P$ iktidara geldiğinde ÇED yerine Stratejik ÇED raporu zorunluluğu getireceğini ve HES'lerin çevresel etki değerlendirmelerini bölge bazında, makro ve mikro ölçekte yapacaklarını beyan etmektedir. HDP ise katılıma vurgu yaparak "Yerel halkın kendi yaşam alanlarındaki her türlü proje hakkında karar vermesini ve ÇED vb. süreçlerin demokratikleşmesini sağlayacağız" vaadinde bulunmaktadır. 


\section{Sonuç ve Öneriler}

Seçim bildirgeleri incelendiğinde 17 yıldır iktidarı elinde tutan $A K$ Parti'nin ağırlığı hissedilmektedir. Metin genişliği ve söylem çeşitliliği bakımından $A K$ Parti diğer partilerin çok önündedir. $A K$ Parti önceliği iktidarı döneminde yaptıklarına vermekte, yaptıklarını yapacakları için teminat olarak göstermektedir. Fakat $A K$ Parti abartılı ve gerçekte karşılığı olmayan bazı bilgilere de seçim beyannamesinde yer verdiği için inandırıcılığını yitirmektedir. Örneğin; HES'leri çevreyi koruyan bir enerji üretim aracı olarak göstermekte, ağaçlandırma rakamlarını daha önce olduğu gibi yine abartılı vermektedir. AK Parti'nin kendini övdüğü bu tür hususların bir kısmı muhalefet partileri için eleştiri şansı doğurmakta, bir sorun olarak tespit ettikleri bu konuları çözeceklerini beyan etmektedirler.

24 Haziran 2018 Genel Seçiminde $A K$ Parti ile Cumhur İttifakı çatısı altında birlikte hareket eden $M H P$ kendi adına beyanda bulunmak yerine çoğunlukla mevcut $A K$ Parti hükümetini yönlendirmeye yönelik bir dil kullanmıştır.

$C H P, I P, S P$ ve $H D P$ gibi muhalefet partileri $A K$ Parti'ye göre ormanları ve doğayı koruma konusunda daha kesin ve iddialı ifadeler kullanmaktadır. Fakat bunun nedeni; iktidarın dışında olmaları nedeniyle görüşlerini oluştururken kendilerini bağlayıcı hiçbir sınırlamaya tabii olmamaları olabilir.

İktidar partisinin de muhalefet partilerinin de birçok konuya yaklaşımı yüzeysel düzeydedir. Genellikle slogan düzeyinde kalan vaatlerinde, somut yol ve yöntemler önermemektedirler. Hatta partilerin önceki seçim bildirgelerinde kullandıkları bilgileri biraz rötuşlayıp yeni bildirgelerine koydukları söylenebilir.

Partiler Çevre / Doğa koruma / Ormancılık üçgeninde asıl ağırlığı kendilerince de toplumun daha çok ilgisini çekeceğini düşündükleri için çevre konularına vermektedir. Bu nedenle ormanlar konusunun siyasi partilerin ilgisini daha çok çekecek hale getirilmesi için ormancılık camiasına önemli görevler düşmektedir.

Siyasi partiler, geçmişte olduğu gibi günümüzde de ormanları sadece kırsal kesimlerle ilgili bir varlık olarak görmeye devam etmekte, ormanların uluslararası önemini ve kentli topluluklar için değerini kavrayamamaktadırlar. Ormanların küresel ölçekte değişen rolü ile kentli topluluklara sundukları hizmetlerin politika oluşturmada siyasi partiler tarafından da dikkate alınması gerekmektedir.

Ormanların yönetiminde en etkili ilgi gruplarından birini oluşturan siyasi partilerin ormanlara olan ilgisini ortaya koymaya çalışan bu ve bundan önceki çalışmaların siyasi partilere ve diğer ilgi gruplarına yol göstermesi için; bu tür çalışmaların sayısının arttırılması ve yaygınlaştırılması ülke ormanları ve ormancılığı için büyük yarar sağlayacaktır.

\section{Teşekkür}

Makalemizi değerlendiren saygıdeğer hakemlere kıymetli katkılarından dolayı teşekkür ederiz.

\section{Kaynaklar}

1. Akay, A., Akgün, F. K. (2014). Türkiye'de planlamada dönüşüm süreci: Çevre ve Koruma mı? Kentleşme ve Yapılaşma mı? Amme İdaresi Dergisi, 47(4): 93-115.

2. Akçay, E. Y. (2018). 24 Haziran seçimleri sürecince siyasi partilerin seçim beyannamelerinde Avrupa birliği ile ilişkiler. Uluslararası Toplum Araştırmaları Dergisi, 8(15): 2175-2192.

3. AK Parti (2018). Adalet ve Kalkınma Partisi Cumhurbaşkanlığı Seçimleri ve Genel Seçimler Seçim Beyannamesi. 360s. http://www.akparti.org.tr/site/dosya/59647

4. Atmiş, E. (2003). Ormanlarımız ve siyasal partiler. Cumhuriyetimizin 80. Yılında Bitkisel Üretim Hayvancılık ve Ormancılığımız Kongresi (3 Kasım 2003) Bildiriler Kitabı. Tarım Orkam-Sen Yayını, Ankara, s:189-209.

5. Atmiş, E. (2008). 2007 Genel seçim bildirgeleri çerçevesinde siyasi partiler ve ormancılık ilişkileri. Bartın Orman Fakültesi Dergisi 10(14): 33-42.

6. Atmiş, E. (2016). Development of urban forest governance in Turkey. Urban Forestry \& Urban Greening, 19: $158-166$.

7. Atmiş, E. (2018). A critical review of the (potentially) negative impacts of current protected area policies on the natüre conservation of forest in Turkey. Land Use Policy, 70: 675-684. 
8. Atmiş, E., Günşen, H. B., Özden, S. (2009). How can Turkey's forest cooperatives contribute to reducing rural development? Unasylva, 234-235(61): 51-53.

9. Atmiş, E., Günşen, H. B. (2011). 2011 Genel seçimlerinde siyasi partiler ve ormancılık ilişkileri. Kastamonu Üniversitesi Orman Fakültesi Dergisi 11(2):191-204.

10. Atmiş, E., Günşen, H. B. (2013). AK parti hükümetlerinin ormancılık politika ve uygulamalarının sürdürülebilir orman yönetimi kapsamında analizi. Orman Mühendisliği, 50(10-11-12): 8-23.

11. Atmiş, E., Günşen H. B. (2016). Türkiye'de 2015 yılı genel seçimlerinde siyasal partiler ve ormancılık ilişkileri. İstanbul Üniversitesi Orman Fakültesi Dergisi, 66(2): 587-599.

12. Atmiş, E., Günşen H. B. (2018a). Comparative analysis of forestry policy and implementation of AK Party period in Turkey. International Forestry Review, 20(4): 405-419.

13. Atmiş, E., Günşen H. B. (2018b). Degradation Caused by Run-of-the-River Hydroelectric Power Plants On Forests and Local Communities in Turkey. International Symposium Ecology 2018, June 19-23, 2018. Kastamonu/Turkey. P: 305.

14. Aymankuy, Y., Demirbulut, Ö. G., Aymankuy, Ş. (2016). Türkiye'de siyasi partilerin seçim beyannamelerinde turizmin yeri - haziran 2015 genel seçimleri örneği. Mehmet Akif Ersoy Üniversitesi Sosyal Bilimler Enstitüsü Dergisi, 8(16): 292-302.

15. Aytaç, S. E. (2017). Türkiye'de siyasi partilerin seçim beyannamelerindeki politika öncelikleri, 2012-2015. Siyasal: Journal of Political Sciences, 26(2): 7-26.

16. Bowen, G. A. (2009). Document analysis as a qualitative research method. Qualitive Research Journal, 9(2): $27-40$.

17. CHP (2018). Cumhuriyet Halk Partisi Seçim Bildirgesi Millet İçin Geliyoruz. 231 s. http://secim2018.chp.org.tr/files/CHP-SecimBildirgesi-2018-icerik.pdf

18. Coşgun, U. (2015). OGM Personel Atamalarının Ormancılık Araştırma Enstitü Müdürlüklerindeki Hukuksal ve Teknik Boyutlarının Değerlendirilmesi. IV. Ormancılıkta Sosyo-Ekonomik Sorunlar Kongresi Bildiriler Kitab1, Trabzon, s:413-424.

19. Coşkun, A. K., Türker, M. F., Öztürk A. (2015). Türkiye'de tek başına iktidar olan partilerin seçim beyannameleri ve hükümet programlarında ormancılık. Artvin Çoruh Üniversitesi Orman Fakültesi Dergisi, 16(1): 72-88.

20. Cubbage, F. W., O'laughlin, J., Bullock, C. S. (1993). Forest resource policy. John Wiley and Sons, Inc..

21. Çağlar, Y. (1979). Türkiye'de Ormancılık Politikası (Dün). Ankara: Çağ Matbaası.

22. Çağlar, Y. (2007). Siyasal Partilerin Ormanlarımıza ve Ormancılığımıza Yaklaşımları. Ormancılığımızın Demokratikleşmesi İçin Birlikte Yürüyüş Serisi. 15 S. Ankara.

23. Çağlar, Y. (2015). Siyasal Partiler Ormancılığımız ile Ormanlarımızda da Havanda Su Dövüyor. Ormanlar ve Ormancılık Üzerine Sessiz Tartışmalar Serisi. Basılmamıştır.

24. Çarkoğlu, A. (1998). The Turkish party system in transition: party performance and agenda change. Political Studies, XLVI: 544-571.

25. Çelik, Ö. (2012). Siyasi partilerin ve adayların seçim harcamalarının sınırlandırılması. Amme İdaresi Dergisi. 45(3): 109-128.

26. Daşdemir, İ. (2011). Dikili ağaç satışlarının uygulanması üzerine değerlendirmeler. Bartın Orman Fakültesi Dergisi, 13(20): 71-79.

27. Erdönmez, C., Atmiş, E., Özden, S. (2010). Türkiye'de Ormancılık Politikası. In: Akesen, A., Ekizoğlu, A. (Eds.) Ormancılık Politikası. Türkiye Ormancılar Derneği Yayını, Ankara, pp: 101-146.

28. Erdönmez, C. (2013). 2B alanlarının satışının Türkiye ulusal ormancılık programı açısından irdelenmesi. Kastamonu Üniversitesi Orman Fakültesi Dergisi, 13(2): 307-324.

29. Eryılmaz, A. Y. (1985). Ormancılık Politikası Ders Notları. KTÜ Orman Fakültesi Yayını, Trabzon.

30. Gümüş, C. (2004). Ormancılık Politikası (Cilt 1). KTÜ Orman Fakültesi Yayını, Trabzon.

31. Gümüş, C. (2014). Osmanlıdan günümüze ormancılık politikalarının ormancılık örgütlenmesi üzerine etkileri ve güncel sorunlar. II. Ulusal Akdeniz Orman ve Çevre Sempozyumu Bildiriler Kitabı. 22-24 Ekim 2014. Isparta. S:447-489.

32. Günay, T. (2003). Ormancılı̆̆ımızın Tarihçesine Kısa Bir Bakış. Tarım Orkam-Sen Yayınları. Ankara.

33. Günşen, H. B., Atmiş, E. (2017). Doğa turizmi master planlarının doğa turizmini geliştirmesindeki katk1 düzeyi. 1. Uluslararası Sürdürülebilir Turizm Kongresi Bildiriler Kitabı. 23-25 Kasım 2017, Kastamonu, s:207-221.

34. Günşen, H. B., Atmiş, E. (2018). Türkiye'de Odun Dışı Orman Ürünleri Üretimi Üzerine Analizler. 4. Uluslararası Odun Dışı Orman Ürünleri Sempozyumu Bildiriler Kitabı, 4-6 Ekim 2018, Bursa, s:191-202.

35. Günşen, H. B., Atmiş, E. (2019). Analysis of change and deforestation in forests in Turkey. International Forestry Review, 21(2): 182-194.

36. HDP (2018). Halkların Demokratik Partisi Seçim Bildirgesi. 92s. https://www.hdp.org.tr/tr/materyaller/secim-arsivi/24-haziran-secimleri/11967 
37. İP (2018). İyi Parti Seçim Beyannamesi Milletimizle Sözleşme. 134s. http://iyiparti.org.tr/assets/pdf/secim beyani.pdf

38. Kapani, M. (2016). Politika Bilimine Giriş. BB101 Yayınları, Ankara.

39. Karpat, K. H. (2013). Türk Demokrasi Tarihi. Timaş Yayınları, İstanbul.

40. Kiriş, H. M., Gül, H. (2008). Türkiye'de siyasal eğilimlerin dönüşümü: yerel seçimler bağlamında bir çözümleme. Amme İdaresi Dergisi. 41(2): 101-129.

41. Krott, M. (2005). Forest Policy Analysis. Springer, The Netherlands.

42. MHP (2018). Milliyetçi Hareket Partisi Seçim Beyannamesi Milli Diriliş Kutlu Yükseliş. 130s. https://www.mhp.org.tr/usr_img/_mhp2007/kitaplar/24haziran2018 secim beyannamesi_tam_web.pdf

43. Mutlu, A. (2008). Ekolojik sorunlara karşı benimsenen yaklaşımlarda yönetim düşüncesi. Amme İdaresi Dergisi, 41(4): 101-123.

44. Neuendorf, K. A. (2017). The Content Analysis Guidebook. Second Edition. SAGE Publications. USA.

45. OGM (2012). Orman Genel Müdürlüğü 2013-2017 Stratejik Planı. Orman Genel Müdürlüğü, Ankara.

46. OGM (2018). Orman Genel Müdürlüğü Resmi Ormancılık İstatistikleri 2017. https://www.ogm.gov.tr/ekutuphane/Sayfalar/Istatistikler.aspx Erişim: 15.11.2018.

47. Özdönmez, M., İstanbullu, T., Akesen, A., Ekizoğlu, A. (1996). Ormancılık Politikası. İstanbul Üniversitesi Orman Fakültesi Yayını. İstanbul. $417 \mathrm{~s}$.

48. Quinn, T. (2010). Mandates, Manifestos and Coalitions: UK Party Politics after 2010. The Constitution Society, UK.

49. Radkau, J. (2017). Doğa ve İktidar Global Bir Çevre Tarihi. İstanbul: Türkiye İş Bankası Kültür Yayınları.

50. REGA (1950a). 31 Mart 1950 tarihli ve 7471 sayılı T.C. Resmi Gazetesi.

51. REGA (1950b). 03 Nisan 1950 tarihli ve 7473 sayılı T.C. Resmi Gazetesi.

52. REGA (1987). 28 Mayıs 1987 tarihli ve 19473 sayılı T.C. Resmi Gazetesi.

53.SP (2018). Saadet Partisi Seçim Beyannamesi Türkiye Vizyonu. 199s. https://www.saadet.org.tr/dosyalar/1528900020beianname.pdf

54. Şeşen, E., Ertürk, K. Ö. (2017). Türkiye'de 1990 sonrası çevre politikalarının seçim beyannamelerine yansıması. Selçuk İletişim, 10(1): 188-215.

55. Tiyek, R. (2015). Sosyal politika kapsamında seçim bildirgelerinin değerlendirilmesi. Emek ve Toplum, 4(9): 36-63.

56. Tok, T. N. (2012). Türkiye'deki siyasal partilerin eğitim söylemleri ve siyasaları. Kuram ve Uygulamada Eğitim Yönetimi, 18(2): 273-312.

57. Tokgöz, O. (1994). 1991 genel seçiminde refah partisi: siyasal reklamlarda yer alan imgeler ve söylem üzerinde bir araştırma. Amme İdaresi Dergisi, 27(1): 19-41.

58. Tosun, G., Tosun, T. (1995). Türkiye'de kentleşme-siyasal yapılanma ilişkisi. Amme İdaresi Dergisi, 28(4): 445-63.

59. VP (2018). Vatan Partisi Seçim Bildirgesi. 58s. http://vatanpartisi.org.tr/dosyalar/27/442121.pdf

60. Yargıtay (2018). Türkiye Cumhuriyeti Yargıtay Cumhuriyet Başsavcılığı. Erişim: 16.10.2018. https://www.yargitaycb.gov.tr/sayfa/faaliyette-olan-siyasi-partiler/documents/Spartiler19072018.pdf

61. Yıldırım, H. D., Ayanoğlu, S. (2014). 6292 sayılı yasa hakkında düşünceler. İstanbul Üniversitesi Orman Fakültesi Dergisi, 64(1): 1-11.

62. YSK (2018). Yüksek Seçim Kurulu 24 Haziran 2018 Genel Seçimi Sonuçları. http://www.ysk.gov.tr/tr/24haziran-2018-secimleri/77536 Erişim tarihi: 30 Temmuz 2018.

63. Yurdakul Erol, S., Yıldırım, H. T. (2017). A qualitative and quantitative analysis of Turkish forest policy documents in the rural development scope. Ciencia Rural, 47(6): 1-9. 